\title{
The geochemistry of the Yangtze River: Seasonality of concentrations and temporal trends of chemical loads
}

\author{
Beat Müller, ${ }^{1}$ Michael Berg, ${ }^{2}$ Benoît Pernet-Coudrier, ${ }^{2}$ Weixiao Qi, ${ }^{3}$ and Huijuan Liu ${ }^{3}$ \\ Received 16 December 2011; revised 11 April 2012; accepted 16 April 2012; published 31 May 2012.
}

[1] The Yangtze is the largest river in Asia and its water composition reflects the activities of about 400 Mio people in its catchment. Its chemical loads have a large impact on the biogeochemistry of the East China Sea. We discuss and quantify the annual dynamics of major ions, nutrients, and trace elements from samples collected monthly at Datong Station from May 2009 to June 2010. The Yangtze today carries $192 \times 10^{6}$ tons of total dissolved solids annually to the East China Sea, which is an increase of $25 \%$ compared to the average of 1958-1990. While the loads of dissolved silica $\left(\mathrm{SiO}_{2}\right)$, dissolved inorganic carbon (DIC), $\mathrm{Ca}^{2+}$ and $\mathrm{Mg}^{2+}$ compared well with the long-term averages since the $1950 \mathrm{~s}$, loads of $\mathrm{Na}^{+}, \mathrm{Cl}^{-}, \mathrm{SO}_{4}^{2-}$, have tripled since $1958-1990$. The increase of $\mathrm{SO}_{4}^{2-}$ is attributed to the burning of coal in the catchment, and $18 \%$ of the $\mathrm{F}^{-}$load is estimated to originate from this source. The increase of $\mathrm{Na}^{+}$and $\mathrm{Cl}^{-}$loads may be anthropogenic as well. The load of dissolved inorganic nitrogen (DIN) has increased 15 fold since the early measurements around 1970 and amounts to $1.6 \mathrm{Mt}-\mathrm{N} / \mathrm{yr}$ today. The particulate concentrations of the typical anthropogenic trace metals $\mathrm{Cd}, \mathrm{Cr}, \mathrm{Cu}, \mathrm{Ni}, \mathrm{Pb}$, and $\mathrm{Zn}$ showed enrichment factors between 0.7 - 7 compared to the natural background. Their annual peak concentrations all exceeded the quality targets recommended by the EC up to two times. However, the load of trace elements at Datong decreased by $73-86 \%$ (As: $50 \%$ ) in the past ten years.

Citation: Müller, B., M. Berg, B. Pernet-Coudrier, W. Qi, and H. Liu (2012), The geochemistry of the Yangtze River: Seasonality of concentrations and temporal trends of chemical loads, Global Biogeochem. Cycles, 26, GB2028, doi:10.1029/2011GB004273.

\section{Introduction}

[2] Due to the fast economic and social developments in China, the environment and particularly the surface water ecosystems are under great threat. The Yangtze River, or Changjiang, is the longest river in Asia $(6300 \mathrm{~km})$ and the 5 th largest in the world by discharge $\left(900 \mathrm{~km}^{3} / \mathrm{yr}\right)$. Even though water scarcity and withdrawal is not an issue, the list of devastating changes in the river basin is long. Some of the most apparent issues are the decreasing particle discharge [Chen et al., 2008], the disappearance of about 800 lakes over the last 50 years, $75 \%$ decline of fish stocks due to overfishing (including the extinction of the freshwater dolphin, the Baiji [Turvey et al., 2007]), increase of population,

\footnotetext{
${ }^{1}$ Eawag, Swiss Federal Institute of Aquatic Science and Technology, Kastanienbaum, Switzerland.

${ }^{2}$ Eawag, Swiss Federal Institute of Aquatic Science and Technology, Dübendorf, Switzerland.

${ }^{3}$ Research Center for Eco-Environmental Science and Technology, Chinese Academy of Sciences, Beijing, China.

Corresponding author: B. Müller, Eawag, Swiss Federal Institute of Aquatic Science and Technology, CH-6047 Kastanienbaum, Switzerland. (beat.mueller@eawag.ch)

Copyright 2012 by the American Geophysical Union. 0886-6236/12/2011GB004273
}

discharge of raw sewage, dense and increasing boat traffic, ongoing construction of dams and levies that interrupt the longitudinal and lateral connectivity of the river and cut off particle transport, seasonal shift of water discharge due to hydropower generation and management of the reservoirs [Dudgeon, 2010; Chibamba et al., 2009].

[3] Water quality of the middle and lower part of the Yangtze has so far not been critical due to the dilution of loads by the enormous amounts of water [Müller et al., 2008]. However, the composition of river water and its temporal changes and trends reveal natural weathering processes as well as anthropogenic activities within the catchment basin. As the Yangtze River integrates the activities of $35 \%$ (400 Mio) of the Chinese population living in a catchment covering almost $20 \%$ of this country's area, its analysis is an invaluable indicator for changes and visualizes major processes. The comparison of the Yangtze River's element loads, hydrology and particle transport - especially when compared with earlier measurements - reflects significant developments in its drainage basin that also may affect the East China Sea. The recent work by Chetelat et al. [2008] has addressed this issue of characterizing the impact of anthropogenic activities compared to natural processes.

[4] Control of water quality is also essential for the largest water diversion ever attempted, the South-to-North Water Transfer Project [Berkoff, 2003; Yang and Zehnder, 2005]. 
The system is already partly functional (the Grand Canal Eastern Route) and partly under construction (Central Route, completion planned for 2014) and shall divert $44 \mathrm{~km}^{3} / \mathrm{yr}$ (about 5\% of the river's annual discharge) to the northern provinces [Jiang, 2009]. Valuable water is transported in open canals for domestic and industrial purposes. Certainly, such a project includes an elaborate monitoring program along the layout of the canals, and detailed knowledge on the water quality of the source, the Yangtze River, is imperative. With this respect, our present study may serve as a baseline compilation of parameters to assess future changes.

[5] Human activity has so far not significantly altered the total annual water discharge of the Yangtze, contrary to drainage basins in the north of China where most surface waters are heavily affected by overuse and overexploitation of groundwater for irrigation and industry [Xu et al., 2010]. In 2000 the water consumption in the Yangtze basin amounted to $83 \mathrm{~km}^{3} / \mathrm{yr}$, which is $<10 \%$ of the river's total discharge of around $900 \mathrm{~km}^{3} / \mathrm{yr}$.

[6] Energy production at the Three Gorges Dam (TGD) alters the water discharge of the Changjiang only on short time scales, as the reservoir capacity is only about $5 \%$ of the river's annual runoff $[X u$ et al., 2010]. However, the many dams under construction or in planning [Dudgeon, 2010; China Three Gorges Project Corporation, 2007] will change the once mighty Yangtze into a series of reservoirs entirely devoid of river characteristics, thus altering the flora and fauna of the river and its shores. The most discussed issue in this context is the decrease of the particle load.

[7] The history and causes for changes of the Yangtze's particle load since 1951 are well documented and discussed [Chen et al., 2008; Wang et al., 2007; S. Yang et al., 2006; Zhang et al., 2006]. Recently, Wang et al. [2008] extended this period backward to 1860 applying a model predicting particle concentration as a function of the measured water discharge rates. A significant decrease of the suspended particle load occurred in the last 50 years not only due to the construction of dams and water gates of various sizes, but also because of reforestation projects and other programs to reduce soil erosion [Z. Yang et al., 2006]. An unprecedented low is experienced since the closing of the TGD in June 2003 where the long-term annual average of $470 \mathrm{Mt} / \mathrm{yr}$ before the construction of the main dam decreased to $130-140 \mathrm{Mt} / \mathrm{yr}$ today of which $40 \%$ is even attributed to channel erosion in the middle reaches of the Yangtze [Yang et al., 2010]. These authors also document the erosion of the Yangtze delta region at Shanghai.

[8] Changing loads of major ions are important indicators for large-scale alterations of geochemical processes probably due to anthropogenic impacts. Valuable long-term data published by Chen et al. [2002] from the period 1958-1990 revealed an increasing trend in sulfate $\left(\mathrm{SO}_{4}^{2-}\right)$ and chloride $\left(\mathrm{Cl}^{-}\right)$concentrations. While the former was attributed to the increasing consumption of the local sulfur-rich brown coal with subsequent air pollution and acid rain, the latter remained unexplained.

[9] Increasing cultivation and changes in agricultural practices have led to a tremendous increase of nitrogen $(\mathrm{N})$ fertilizer application in the last 40 years. China is now the world's largest producer and consumer of $\mathrm{N}$ fertilizers, polluting surface and groundwaters as well as coastal areas, and also increasing its energy consumption and greenhouse gas emission [Kahrl et al., 2010]. In the year 2005 Bao et al. [2006] presented a $\mathrm{N}$ budget for the catchment of the Yangtze for the years 1980 and 1990 stating that anthropogenic $\mathrm{N}$ fluxes by far exceeded the natural cycle. The strong promotion of $\mathrm{N}$ fertilizers in China as a consequence of the agricultural reform in 1978 has led to a surplus application, exceeding the demand for crop production. Duan et al. [2007] observed increasing concentrations of nitrate since 1980, and Yan et al. [2003] reported that nitrate concentrations had increased tenfold in the period 1968-1997 because of $\mathrm{N}$ fertilizer application. At present, $>90 \%$ of $\mathrm{N}$ discharged into the Yangtze originates from agriculture [Chibamba et al., 2009]. Consequently, in the rice, wheat and corn production the efficiency of $\mathrm{N}$ fertilizer ( $\mathrm{kg}$ yield / $\mathrm{kg} \mathrm{N}$ ) decreased from 164 to 10 , from 44 to 6 , and from 93 to $9 \mathrm{~kg}$, respectively [Tong et al., 2003]. Ju et al. [2009] estimated that fertilizer application could be reduced by $30-60 \%$ without any loss for crop yields. If these insights will change the behavior in the future we can expect to observe a 'peak nitrogen' phase, where a more efficient application will decrease the $\mathrm{N}$ loss to surface waters. Thus, future observation of this river might efficiently document the effect of a more responsible handling of $\mathrm{N}$ fertilizers in the future.

[10] On the contrary, phosphorus (P) concentrations decreased after the closing of the TGD in 2003, resulting in potential P limitation for primary production downstream [Chai et al., 2009]. Similarly, dissolved silica has decreased since the 1950 s caused by primary productivity and its retention in the many reservoirs [Li et al., 2007]. As a result, the nutrient ratio Si: N: P has shifted markedly from the predominance of $\mathrm{Si}$ to that of $\mathrm{N}$. It appears that productivity of the coastal waters is no longer $\mathrm{N}$ but $\mathrm{P}$ limited [Wang et al., 2003], and there is strong evidence that the increasing ratio of $\mathrm{N}: \mathrm{Si}$ is responsible for the increasing occurrences of harmful algae blooms in coastal waters [Anderson, 2009].

[11] Zhang et al. [1990] and Zhang [1995] were the first to report trace metals in the Yangtze and its estuary. Generally, no anthropogenic influences could be quantified, and metal ion contents of the particulate matter transported by the Yangtze were attributed to natural weathering processes. This was confirmed by Chen et al. [2004] finding surprisingly low contents of 17 heavy metals in sediment cores from the Yangtze estuary, which they attributed to the dispersal of the heavy pollution from Shanghai to the enormous amount of suspended particulate matter transported by the Yangtze. Song et al. [2010] recently published an overview of trace element contents of suspended particulate matter in 75 locations all over the Yangtze River basin localizing three mining areas as main sources of pollution.

[12] In November 2006 we investigated the middle and lower part of the Yangtze River - from the TGD downstream to Shanghai - presenting a snapshot overview of the longitudinal distribution of polluting chemicals [Müller et al., 2008]. The present study complements this former work with monthly measurements over the course of 14 months at one spot, at Datong. Here we analyzed concentrations of major ions, macronutrients, and trace elements. We discuss seasonal variations and estimate annual loads. Results are compared with data reported in earlier studies, and from the temporal development we estimate anthropogenic contributions to the present loads. We thus provide a database for a 


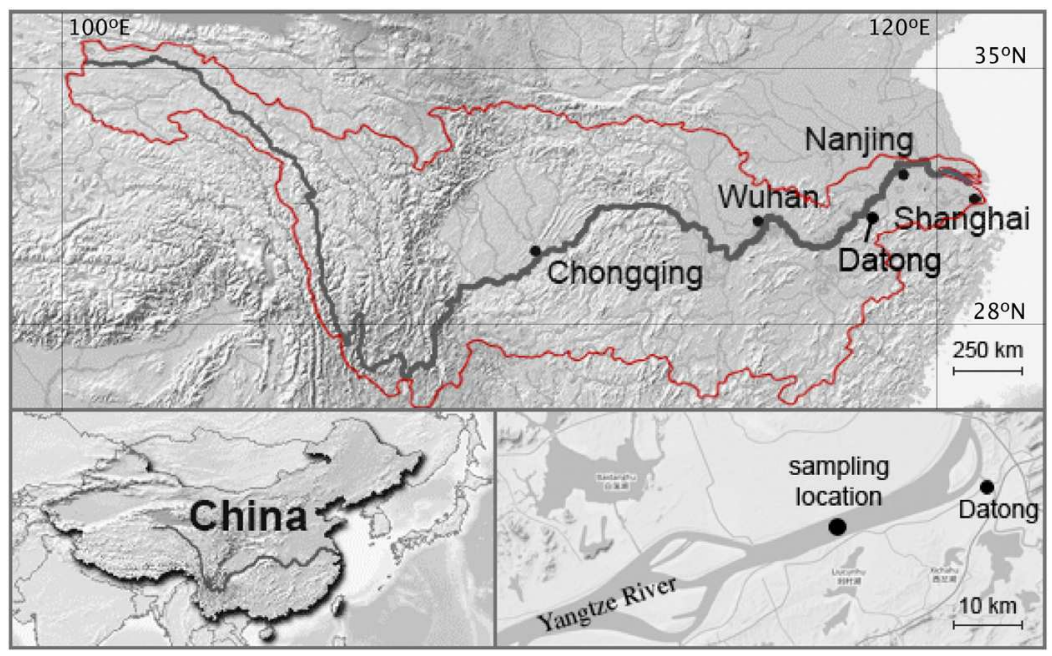

Figure 1. Map of the Yangtze River and its catchment. The bottom right map shows the three sampling locations across the river near Datong.

better understanding of this river system that currently undergoes major changes.

\section{Materials and Methods}

[13] Samples were collected monthly from May 2009 to June 2010 about $12 \mathrm{~km}$ upstream of the bridge of Datong, approx. $600 \mathrm{~km}$ from the East China Sea (Figure 1), draining a catchment area of 1.7 million $\mathrm{km}^{2}$ [Zhang et al., 2006]. Three samples were collected in the cross section of the river

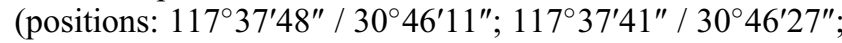
$\left.117^{\circ} 37^{\prime} 33^{\prime \prime} / 30^{\circ} 46^{\prime} 53^{\prime \prime}\right)$ from $0.5 \mathrm{~m}$ depth with a ship using a steel sampler controlled by the EK-II depth sounder. Water discharge at the Datong gauge station for 2009 was obtained from the station manager while the values for 2010 were collected daily from http://xxfb.hydroinfo.gov.cn/EN/eindex.jsp. Data of temperature, $\mathrm{pH}$, conductivity $\left(\kappa_{20}\right)$ and dissolved oxygen $\left(\mathrm{O}_{2}\right)$ were obtained from the station manager.

[14] Water samples were filtered in the field with a plastic syringe through pre-rinsed $0.45 \mu \mathrm{m}$ pore size cellulose acetate membrane filters of $47 \mathrm{~mm}$ diameter (Beihua Liming Co., Beijing). Acid washed polypropylene filter holders from Millipore were used. The filtrates were acidified with $100 \mu \mathrm{l}$ of suprapure $\mathrm{HNO}_{3}$ (Beijing Chemical Factory) for trace element analysis. One sample was not acidified and used for ion chromatographic analysis of anions and cations (Metrohm, Switzerland). Samples were then shipped to Switzerland and analyzed at Eawag. Alkalinity was titrated with $0.1 \mathrm{M} \mathrm{HCl}$ and analyzed with a Gran plot [Stumm and Morgan, 1996, p. 179ff]. Silica, nitrate, ammonium, and dissolved inorganic phosphorus (DIP) were determined colorimetrically from filtered samples according to standard methods [Deutsches Institut für Normung, 2002]. Total phosphorus (TP) and total nitrogen (TN) were determined photometrically from unfiltered samples after digestion with $\mathrm{K}_{2} \mathrm{~S}_{2} \mathrm{O}_{3}$ for $2 \mathrm{~h}$ at $120^{\circ} \mathrm{C}$ in an autoclave. Samples for total dissolved phosphorus (TDP) and total dissolved nitrogen (TDN) were digested with the same method but from filtered samples. Ion charge balance for inorganic ions was between $-6.2 \%$ to $+0.3 \%$ in all samples. Dissolved organic carbon (DOC) was analyzed after oxidation in
UV light with an Elementar TOC Shimadzu 5000A analyzer. Particulate organic carbon (POC) was measured by combustion from a glass fiber filter of $47 \mathrm{~mm}$ diameter and $0.45 \mu \mathrm{m}$ pore size (Beihua Liming Co., Beijing). The trace elements As, B, Ba, Cd, Co, Cr, Cu, Li, Mn, Mo, Ni, Sb, Se, $\mathrm{Sr}, \mathrm{Pb}, \mathrm{Zn}, \mathrm{U}$, and $\mathrm{V}$, as well as major cations $\mathrm{Na}, \mathrm{K}, \mathrm{Ca}$ and $\mathrm{Mg}$ were analyzed from acidified samples with an ICP-MS (Agilent 7500 series). Particulate elements were determined from membrane filters after filtration of a known volume of sample and oxidative acid digestion with $\mathrm{HNO}_{3}$ and $\mathrm{H}_{2} \mathrm{O}_{2}$ in a microwave for 30 min [Deutsches Institut für Normung, 2002]. The samples from the three stations across the river at Datong were analyzed individually and results averaged. Averaged data are given in the auxiliary material. ${ }^{1}$ Only results from July 2009 to June 2010 were used for the estimation of annual loads and average annual concentrations. For every set of samples blank samples and either certified standard solutions (Merck X, TM.28.3, 1643e, and SLRS4, for dissolved samples) or the certified rock standard sample GBW 07305 (including an Eawag-internally used reference sediment) were included. Accuracy levels were between 3\% and $10 \%$ for dissolved samples, $8 \%$ for the Eawag reference sediment, and $18 \%$ for the rock standard. Values for blanks and standards are given in Table S6 in the auxiliary material.

[15] Suspended solids (SS) were determined by weight difference of dried filters $\left(40^{\circ} \mathrm{C}\right)$ before and after filtration independently two times by two experimenters. On the one hand, $0.5-1 \mathrm{~L}$ of water sample was filtered through a glass fiber filter of $0.45 \mu \mathrm{m}$ pore size and $4.7 \mathrm{~cm}$ diameter (Beihua Liming Co., Beijing). On the other hand, 3-4 L of sample were filtered by a $14.2 \mathrm{~cm}$ diameter Whatman glass fiber filter $(0.7 \mu \mathrm{m})$. The results obtained were averaged. Mean variation was $\pm 9 \%$.

[16] Water isotopic composition $\left(\delta^{18} \mathrm{O}\right.$ and $\left.\delta^{2} \mathrm{H}\right)$ was determined by cavity ring-down spectroscopy (Picarro L-1102i, Sunnyvale, CA). Calibration was performed with certified water standards from the International Atomic Energy Agency.

\footnotetext{
${ }^{1}$ Auxiliary materials are available in the HTML. doi:10.1029/ $2011 \mathrm{~GB} 004273$
} 
[17] The flux of $\mathrm{O}_{2}$ (or, similarly, $\mathrm{CO}_{2}$ ) across the waterair interface is described by equation (1) [Alin et al., 2011]:

$$
\mathrm{F}=\mathrm{k}_{600} \mathrm{x}\left(\left[\mathrm{O}_{2(\mathrm{aq})}\right]-\mathrm{K}_{\mathrm{H}} \mathrm{xpO}_{2(\mathrm{~atm})}\right)
$$

F signifies the flux of $\mathrm{O}_{2}\left[\mathrm{~mol} \mathrm{~m}^{-2} \mathrm{~d}^{-1}\right], \mathrm{k}_{600}$ is the freshwater gas transfer velocity at $20^{\circ} \mathrm{C}\left(\mathrm{m} \mathrm{d}^{-1}\right), \mathrm{K}_{\mathrm{H}}$ the temperature dependent Henry coefficient $\left[\mathrm{mol} \mathrm{L}^{-1} \mathrm{~atm}^{-1}\right]$ [Benson and Krause, 1980], $\mathrm{O}_{2(\mathrm{aq})}$ is the concentration in the river water $\left[\mathrm{mol} \mathrm{L}^{-1}\right]$, and $\mathrm{pO}_{2}$ the partial pressure of $\mathrm{O}_{2}$ in the atmosphere $(0.21 \mathrm{~atm})$. The exchange of a gas between water and the atmosphere depends on the concentration difference in the water and the atmosphere, and the turbulence of the water [Zappa et al., 2007], which is mainly caused by the wind. Alin et al. [2011] estimated gas exchange velocities, $\mathrm{k}$, for large rivers and parameterized the relationship with the wind (equation (2)):

$$
\mathrm{k}_{600}=4.46+7.11 \mathrm{u}_{10}
$$

$\mathrm{u}_{10}$ is the wind speed $10 \mathrm{~m}$ above ground. Monthly averages of the wind speed at Chizhou weather station from March 2009 to June 2010 varied between 1.5 and $2.5 \mathrm{~m} \mathrm{~s}^{-1}$.

[18] The estimation of the flux of $\mathrm{CO}_{2}$ is identical, however, $\mathrm{CO}_{2(\mathrm{aq})}$ is calculated from the measurements of $\mathrm{pH}$ and alkalinity. Temperature-dependent Henry coefficients $\left(\mathrm{K}_{\mathrm{H}}\right)$ were calculated with the empirical formula given by Plummer and Busenberg [1982].

\section{Results}

[19] Plots in Figure S1 in the auxiliary material show the seasonality of water discharge, temperature, and concentrations of major elements and nutrients of the monthly samples, starting May 2009 through to June 2010. Water discharge varies strongly by a factor of four to five with annual maxima in July to August, and minimal flow in December to January (Figure S1a). Changes of temperature are shifted by one to two months compared to water discharge, with maxima in September and minima in February. The major ions $\mathrm{Ca}^{2+}$, $\mathrm{Mg}^{2+}$, alkalinity $\left(\mathrm{HCO}_{3}^{-}\right), \mathrm{Na}^{+}, \mathrm{K}^{+}$, and $\mathrm{Cl}^{-}$, tend to increase during the year to reach a peak in January and then decrease forming a distinct minimum at the end of April (Figures S1b and $\mathrm{S} 1 \mathrm{c}$ ). This is only weakly expressed for $\mathrm{K}^{+}$whose concentration is quite constant during the whole year. Silica peaked in August and slightly decreased again during the following months. It may be noteworthy that concentrations are not a mirror image of water discharge, and the annual course of the concentrations seemed not (only) to be controlled by dilution. However, at first glance, loads of these parameters increase almost linearly with water discharge indicating that chemical variations are less important than discharge. A closer look on $\mathrm{SO}_{4}^{2-}$ and $\mathrm{F}^{-}$(Figure S1d) reveals that the shapes of these curves are different from those of other parameters, and they tend much more to mirror water discharge. This could indicate a source different from that of $\mathrm{Ca}^{2+}, \mathrm{Mg}^{2+}$, alkalinity, $\mathrm{Na}^{+}$, and $\mathrm{Cl}^{-}$. The nutrients phosphorus $(\mathrm{P})$ and nitrogen $(\mathrm{N})$ do not show pronounced seasonal cycles (Figures S1e and S1f). Dissolved inorganic $\mathrm{P}$ (DIP) is almost always $<5 \mu \mathrm{gP} / \mathrm{L}$, while total dissolved $\mathrm{P}$ (TDP) and the nitrogen species $\mathrm{NH}_{4}^{+}, \mathrm{NO}_{3}^{-}$, and total dissolved N (TDN) slightly increased during the 14 months sampling period.

[20] The concentrations of major ions and nutrients plotted against water discharge show distinct hysteresis (Figure S2 in the auxiliary material), except for $\mathrm{K}^{+}, \mathrm{SO}_{4}^{2-}$, and $\mathrm{F}^{-}$. For $\mathrm{K}^{+}$and $\mathrm{Si}$ there is no slope visible, while the concentrations of all other parameters increase with decreasing discharge. Thereby, concentrations are higher on the increasing branch of discharge, and lower on the decreasing branch (i.e., the hysteresis runs in a counter-clockwise way; Figures S2aS2c). Contrary, for the nutrient species TDP, $\mathrm{NH}_{4}^{+}, \mathrm{NO}_{3}^{-}$, and TDN the hysteresis runs clockwise, i.e., concentrations are lower on the increasing branch and higher on the decreasing branch of water discharge (Figures S2d and S2e).

[21] Total concentrations of trace elements (dissolved and particulate) peaked together with the two month with high concentrations of suspended particles in July and August 2009 but did not express similar peaks at two later sampling events when the suspended particle concentrations were high again (Figure $\mathrm{S} 3$ in the auxiliary material). Hence, the overall picture was two peaks at the end of the flood season 2009, and subsequently decreasing concentrations until the end of the sampling time (June 2010). Notable exceptions were As, $\mathrm{Mo}, \mathrm{Sb}$, and $\mathrm{U}$. Sr behaved similar to $\mathrm{Ca}^{2+}$.

\section{Discussion}

\subsection{Hydrology}

[22] Due to the seasonal variation in precipitation and snowmelt, water discharge of the Yangtze River is lowest in December / January $\left(11^{\prime} 300 \mathrm{~m}^{3} / \mathrm{s}\right)$ but 4-6 times higher between July and August $\left(64^{\prime} 300 \mathrm{~m}^{3} / \mathrm{s}\right.$, Figure 2). Management of the Three Gorges Reservoir with the purpose of floodwater protection and hydropower production caused a shift in the seasonal water discharge to some extent from autumn to spring irrespective if the weather was dry (2009, red curve) or wet (2010, orange curve) compared to the long-term average (blue and light blue). As the storage capacity of the TGD reservoir is only about $5 \%\left(45 \mathrm{~km}^{3}\right)$ of the annual discharge of about $900 \mathrm{~km}^{3}$ [Xu et al., 2010], its average water residence time is in the order of one and a half month in winter, but only about 10 days at peak flow in summer. The sources of the water masses in the middle and lower Yangtze vary during the year. The winter monsoon (January - May) moves air masses from west to east, while the summer monsoon (June-September) from south to north. [23] The water isotope signatures, $\delta^{2} \mathrm{H}$ and $\delta^{18} \mathrm{O}$, are depicted in Figure 3 and reflect the altitude from where the water originates. The isotopic composition of precipitation is primarily associated with air temperature, altitude, humidity, and the origin of the air masses that carry along the precipitation [Dansgaard, 1964]. Figure 3a plots $\delta^{18} \mathrm{O}$ values at Datong together with the river water discharge. Both, $\delta^{18} \mathrm{O}$ and $\delta^{2} \mathrm{H}$ (not shown) values are decoupled from the amount of precipitation and hence, the river discharge. The $\delta^{18} \mathrm{O}$ signature at Datong shows a flattened pattern compared to annual isotopic fluctuations of precipitation at different altitudes (shaded gray bands). Two circumstances can explain this feature, i) the two types of prevailing monsoon systems that import water from different origins, and ii) the residence time of the water in the TGR as well as the time lag of runoff to reach Datong. 


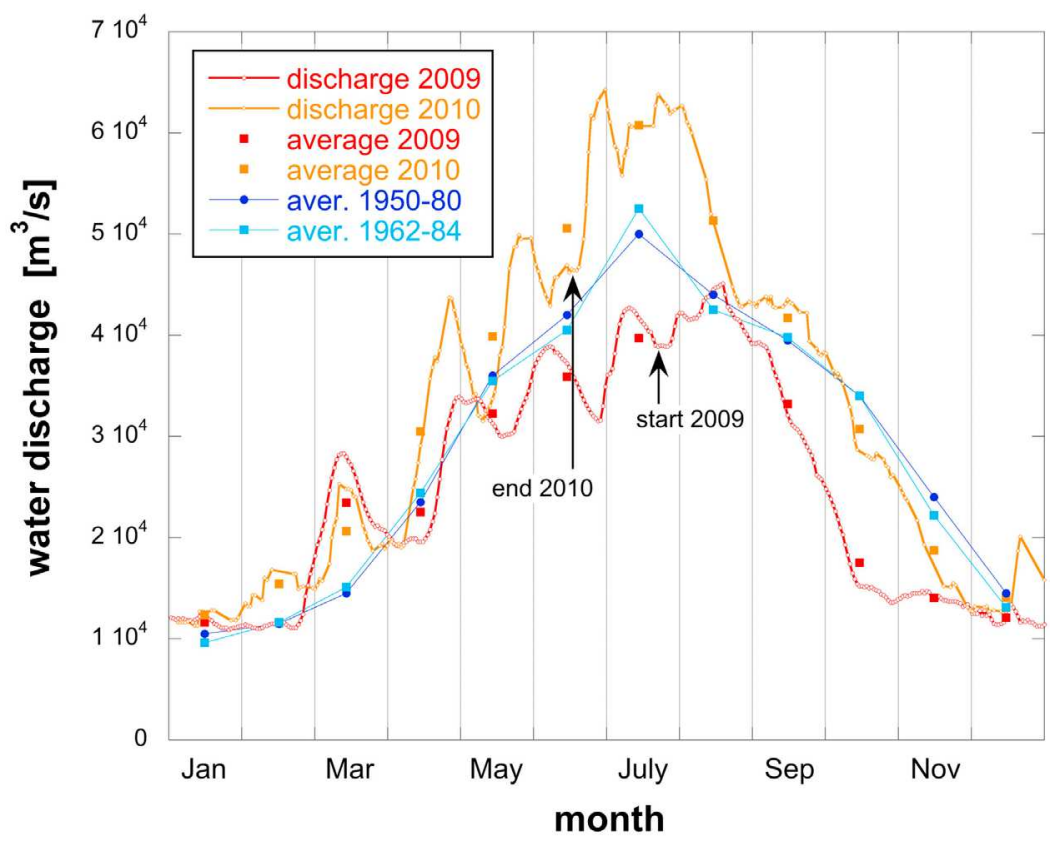

Figure 2. Water discharge at Datong gauge station: monthly averages from approx. 1950-80 [Milliman et al., 1984] (blue dots), and monthly average from 1962 to 84 [Chen et al., 2002] (light blue squares). The red line represents daily values of 2009 (data from Datong hydrological station). Red squares are calculated monthly averages. The orange line depicts daily values collected from online data (http:// xxfb.hydroinfo.gov.cn/EN/eindex.jsp). Orange squares are monthly means calculated from daily values.

[24] The proportion of water from high altitude regions is larger in winter and spring than in summer and autumn due to the westerly winds of the winter monsoon. Rain falls in the upper reaches of the river and flowing time to reach Datong is long. At the same time, water discharge is low and retention time in the reservoir $>1$ month. This may lead to the observed time lag of about 2 months of the $\delta^{18} \mathrm{O}$ peaks compared to the shaded areas. Summer monsoon with its abundant precipitation results in isotopic signatures that are closer to the values typically observed in summer precipitation of the lower and middle reaches. However, the water isotopic values of the Yangtze at Datong always remain lower than in precipitation of the lower and middle reaches, demonstrating that water from the upper Yangtze catchment contributes a significant proportion throughout the year.

[25] The slope of $\delta^{2} \mathrm{H}$ and $\delta^{18} \mathrm{O}$ is slightly steeper in Yangtze water than the world average for precipitation of 8.1 (Figure 3b) [Rozanski et al., 1993]. This indicates that water carried by the Yangtze as close to the sea as Datong was not exposed to sizable evaporation. The deuterium excess $\left(\mathrm{d}=\delta^{2} \mathrm{H}-8 \delta^{18} \mathrm{O}\right)$ [Dansgaard, 1964] varied between 9 and $14 \%$ which is a rather narrow range compared to fluctuations of $>15 \%$ typically observed in local precipitation over the course of a year [Dansgaard, 1964; Yamanaka et al., 2004]. Deuterium excess in precipitation around the globe is generally higher in winter than in summer, however, the Yangtze river water shows an inverse pattern with deuterium excess being lowest during the winter months and highest in summer (Figure $3 b$ ). Among the very few studies published on water isotopes in the Yangtze catchment [e.g., Y. Liu et al., 2008; Cui et al., 2009], two reported a similar pattern of lowest $\delta$-excess values in winter precipitation of Delingha on the Tibetan Plateau, which was attributed to strong continental inland moisture recycling in this alpine region [Tian et al., 2001; Z. Liu et al., 2008]. However, for composite river water at Datong, this inverse deuterium excess must be seen as a function of the overall flow regime in the large Yangtze catchment.

\subsection{Decreasing Load of Suspended Particles}

[26] The load of particles decreased dramatically since the closure of the TGD in 2003. The history of the load of suspended particles is sophisticated as over time various human activities affected erosion (e.g., forest clearing and reforestation), and the construction of $>50^{\prime} 000 \mathrm{dams}$ in the past 60 years resulted in increased retention upstream $[X u$ et al., 2006]. Figure 4 shows how from an average annual load of $482 \mathrm{Mt}$ in the years 1950 to 1980 [Milliman et al., 1984] and $488 \mathrm{Mt}$ for 1865 to 1968 , the average load decreased to only $189 \mathrm{Mt} / \mathrm{yr}$ for the years 2003-2005 [Wang et al., 2008]. A particle load of $61 \mathrm{Mt} / \mathrm{yr}$ resulted from our measurements, which is a further decrease of the $85 \mathrm{Mt}$ determined in 2006 [Chen et al., 2008] and close to the $52 \mathrm{Mt}$ we estimated from the data of the 12-months sampling period of Mao et al. [2010] for 2006/07. The Yangtze today is a 'hungry river' eroding not only its own riverbed but also the subaqueous delta at Shanghai [Yang et al., 2010].

[27] The drop from $189 \mathrm{Mt}$ (average from 2003 to 2005) to $61 \mathrm{Mt} / \mathrm{yr}$ within five years is remarkable and may also be a consequence of the exceptionally low water discharge in the autumn of 2009. We rule out the argument of an immanent artifact that when water is sampled from a boat at the river's surface, particles larger than a critical density and size will not mix with the whole water column but are transported only along the bottom of the river. While it is not possible to 

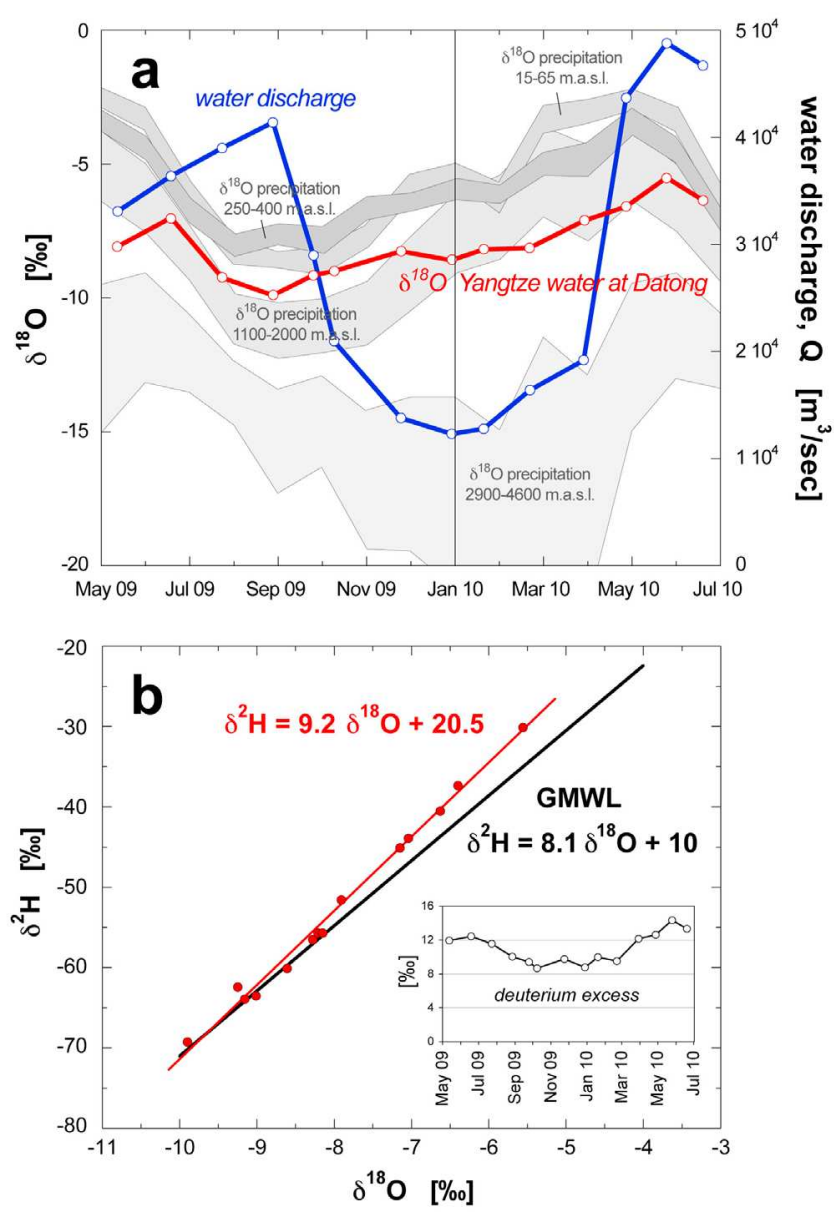

Figure 3. Isotopic composition of Yangtze water samples. (a) The $\delta^{18} \mathrm{O}$ (red) and the water discharge (blue). The gray shaded areas represent the ranges of interpolated (long-term average) $\delta^{18} \mathrm{O}$ values in precipitation of the lower Yangtze reaches (15-65 $\mathrm{m}$ above sea level (a.s.l.), Datong to Yichang), the middle reaches (250-400 $\mathrm{m}$ a.s.l., Chongqing to Leshan), the lower alpine region (1100-2000 m a.s.l., Panzhihua to Shiguzhen), and, the high alpine region (2900-4600 m a.s.1., Bolouxian to Tanggulashanxiang) (G. J. Bowen, The Online Isotopes in Precipitation Calculator, version 2.2, 2011, http://www.waterisotopes.org). (b) Measured ratios of $\delta^{2} \mathrm{H}$ and $\delta^{18} \mathrm{O}$ (red). The black line is the global meteoric water line (GMWL). The inset depicts the deuterium excess.

sample a representative profile from rivers of large depths and with high current velocity without heavy equipment or solid installations, we can estimate the critical particle size where suspended solids can be assumed to be homogeneously mixed in the water column. Generally, the Stokes settling, the depth of the river, and the diffusivity, which again is influenced by the friction velocity at the river bottom, determine the size of particles that can remain in suspension (A. Wüest, Eawag, personal communication, 2011). With a back-of-the-envelope calculation (assuming a mean river depth of $10 \mathrm{~m}$ ) we estimate a cut-off for mineral particles (density $2.5 \mathrm{~g} / \mathrm{cm}^{3}$ ) with diameters $>200 \mu \mathrm{m}$. For organic particles with a density of only $1.07 \mathrm{~g} / \mathrm{cm}^{3}$, particles as large as $0.9 \mathrm{~mm}$ are still transported by the river. Hence, particles of the size $<200 \mu \mathrm{m}$ can be assumed to be homogeneously distributed in the water column of the river. As Mao et al. [2010] report the mean grain size at Datong with $10 \mu \mathrm{m}$ for high discharge in August and $7.9 \mu \mathrm{m}$ for the time of lowest discharge in January, the estimated cut-off at 200 $\mu \mathrm{m}$ is sufficient to include the major particle fraction.

\subsection{Major Ions}

[28] Total annual loads of major elements in the Yangtze estimated from our measurements (23 July 09 to 19 June 2010) are presented in Table 1 . These values summed up give a load of total dissolved solids of $192 \times 10^{6} \mathrm{t} / \mathrm{yr}$. This is an increase of $25 \%$ compared to the average of the years 1962-1990 of $154 \times 10^{6} \mathrm{t} / \mathrm{yr}$ reported by Chen et al. [2002]. The difference is caused mainly by the substantial increases in the sum of $\mathrm{Na}^{+}+\mathrm{K}^{+}, \mathrm{Cl}^{-}$, and $\mathrm{SO}_{4}^{2-}$, while the load of the geogenic parameters $\mathrm{Ca}^{2+}, \mathrm{Mg}^{2+}, \mathrm{HCO}_{3}^{-}$, and $\mathrm{Si}$ remained unchanged.

[29] Conductivity tends to mirror water discharge indicating a dilution effect. Since it is mainly $\mathrm{Ca}^{2+}, \mathrm{Mg}^{2+}, \mathrm{Na}^{+}, \mathrm{Cl}^{-}$, $\mathrm{SO}_{4}^{2-}$ and $\mathrm{HCO}_{3}^{-}$ions that determine ionic strength, this behavior may originate on the one hand from the dilution of (partly) anthropogenic loads of $\mathrm{Na}^{+}, \mathrm{Cl}^{-}$, and $\mathrm{SO}_{4}^{2-}$, but on the other hand also from a very slight dilution of the ions of mainly geogenic origin $\left(\mathrm{Ca}^{2+}, \mathrm{Mg}^{2+}, \mathrm{HCO}_{3}^{-}\right)$. All results are provided in Table $\mathrm{S} 1$ in the auxiliary material. The relationship between the temporal variation of the chemical component's concentrations $(C)$ in a river and its water discharge (Q) is often used to i) characterize the typical behavior of a component, e.g., to distinguish between point sources and diffuse sources [Moosmann et al., 2005], ii) interpolate missing concentrations from water discharge measurements, since these are often easily available, and iii) to estimate loads. An overview and discussion of rating curves encompassing the essential literature was recently published by Meybeck and Moatar [2011]. The decreasing concentration with increasing water load can be described quite accurately with a concentration-discharge (C-Q) relationship of the form

$$
\mathrm{C}_{\mathrm{i}}=\mathrm{aQ}^{\mathrm{b}}
$$

where $C_{i}$ is the concentration of the element $\mathrm{i}, \mathrm{Q}$ is the water discharge, and $a$ and $b$ are fitting parameters where the size of $\mathrm{b}$ is responsible for the bend of the curve, i.e., the dependence of the concentration on water discharge. The parameter $b$ is zero for a hypothetic chemical parameter that is not influenced by seasonal variations of precipitation, temperature, water discharge etc. i.e., its concentration is always constant. The parameter $b$ would be -1 for a hypothetical parameter which was not a constituent of the river water (e.g., a xenobiotica from an industrial production process) which enters the river with a constant rate and therefore is diluted in proportion to the water discharge. In reality, $-1<b<0$ as all chemical parameters are influenced in various ways and to various extents. Similarly, Wang et al. [2008] have determined rating parameters for the load of suspended sediments with a power law. The parameters $b$ for major elements extracted from our data set were $\mathrm{HCO}_{3}^{-}:-0.05 ; \mathrm{Ca}^{2+}:-0.09$; $\mathrm{Mg}^{2+}:-0.22 ; \mathrm{SO}_{4}^{2-}:-0.30 ; \mathrm{F}^{-}:-0.37 ; \mathrm{Si}:-0.03 ; \mathrm{Cl}^{-}$: $-0.64 ; \mathrm{Na}^{+}:-0.51$; and $\mathrm{K}^{+}:-0.15$, and correspond well with the parameterization made by Chen et al. [2002] who presented an overview of data from 191 stations of the years 


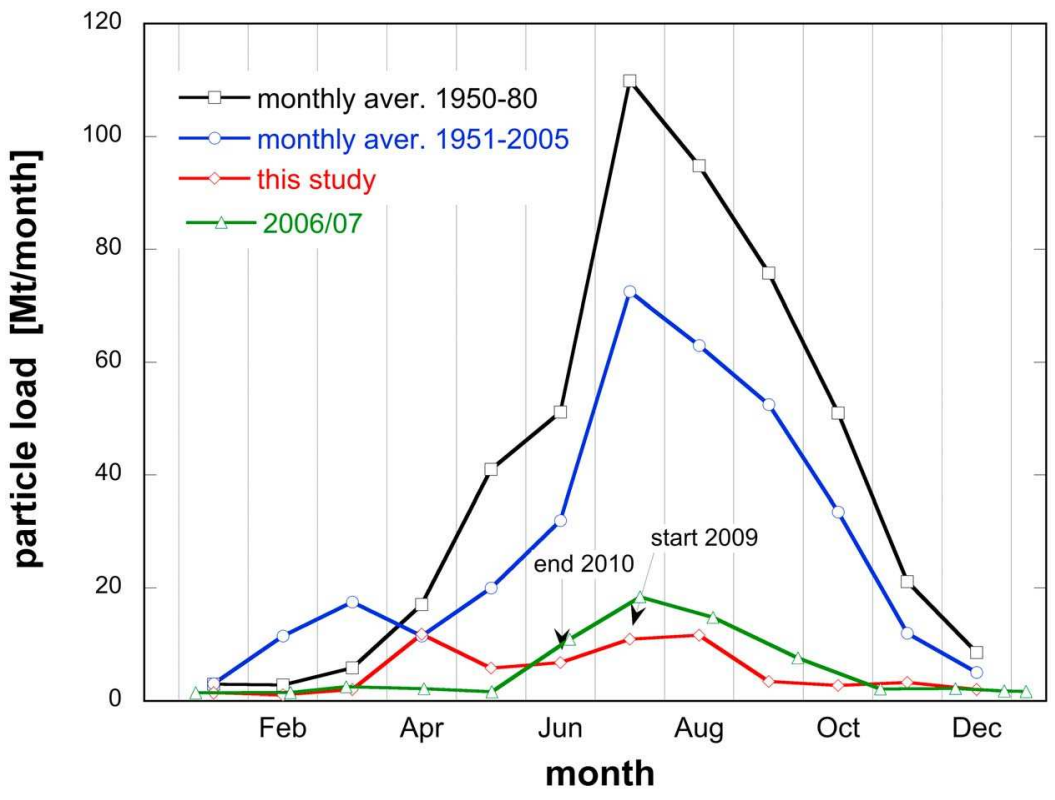

Figure 4. Monthly averaged particle loads from 1950 to 1980 [Milliman et al., 1984] (black squares), 1951-2005 [Wang et al., 2008] (blue dots), 2006/07 [Mao et al., 2010] (green triangles) and from this study (red diamonds). Data of this study start in July 2009 and end in June 2010.

1958-1990. Notable differences were a higher value for $\mathrm{HCO}_{3}^{-}(-0.12)$ and smaller value for $\mathrm{Cl}^{-}(-0.29)$. Obviously, the $b$ values of the mainly geogenic ions $\mathrm{Ca}^{2+}, \mathrm{Mg}^{2+}$, $\mathrm{SiO}_{2}$, and $\mathrm{HCO}_{3}^{-}$deviate less from zero than those for the partly anthropogenic ions $\mathrm{SO}_{4}^{2-}, \mathrm{F}^{-}, \mathrm{Na}^{+}$, and $\mathrm{Cl}^{-}$.

4.3.1. Increasing Trends for $\mathrm{SO}_{4}^{2-}, \mathrm{F}^{-}, \mathrm{Na}^{+}$, and $\mathrm{Cl}^{-}$

[30] The loads of the mainly geogenic constituents $\mathrm{Si}$, $\mathrm{Ca}^{2+}, \mathrm{Mg}^{2+}$, and $\mathrm{HCO}_{3}^{-}$determined for the year 2009/10 match perfectly with the numbers published by Chen et al. [2002] (Table 1). Contrary, $\left(\mathrm{Na}^{+}+\mathrm{K}^{+}\right), \mathrm{Cl}^{-}$, and $\mathrm{SO}_{4}^{2-}$ are about threefold higher today than during 1958-90. These authors pointed already to a significant increase of $\mathrm{Cl}^{-}$ and $\mathrm{SO}_{4}^{2-}$ loads for the period 1962-90. They suspected municipal and domestic sewages as a possible cause for the increased $\mathrm{Cl}^{-}$load and excluded an increased atmospheric transport of sea salt.

[31] The increase of $\mathrm{SO}_{4}^{2-}$ is unambiguously attributed to anthropogenic sources, namely the increased burning of sulfur rich coal in the Chongqing-Guiyang area that became heavily industrialized since the 1970s. Dissolution of gypsum and the oxidation of pyrite are the main natural sources for sulfate. However, as air pollution caused by the burning of coal is a pressing issue especially in the Sichuan and Chongqing provinces [Larssen et al., 2006], atmospheric deposition of sulfur may be a dominant source. Chetelat et al. [2008] assume that chemical weathering reactions even may be dominated by sulfuric acid in some regions. Even though the Chinese authorities pushed for the implementation of flue gas desulfurization in the power plants [Duan et al., 2011], the initiative did not appear to be too effective [Gao et al., 2009]. Burning of coal with sulfur content of 3-5\% [Liu et al., 2006] causes acid rain and high $\mathrm{SO}_{4}^{2-}$ concentration in the rainwater [Larssen et al., 2006]. According to Figure 5 the present-day's coal consumption exceeds the value estimated for the 1960s more than tenfold.
[32] Fluoride concentrations from natural sources such as the dissolution of the minerals apatite, mica, fluorite and cryolite are very small. Rivers comparable to the Yangtze such as the Ganges, Brahmaputra, and Meghna have average concentrations of $8.2 \pm 3.6,6.3 \pm 3.1$, and $3.5 \pm 1.8 \mu \mathrm{mol} / \mathrm{L}$ [Datta et al., 2000]. Livingstone [1963] estimated a global average value for $\mathrm{F}^{-}$in rivers of $5-11 \mu \mathrm{mol} / \mathrm{L}$. Average fluoride concentrations of $11.3 \mu \mathrm{mol} / \mathrm{L}$ from our measurements agree well with the range found by Chetelat et al. [2008] of $5-15 \mu \mathrm{mol} / \mathrm{L}$ over the whole Yangtze basin. Larssen et al. [1999] suggests that fluoride found in the Yangtze is mainly derived from the combustion of coal and enters the river by precipitation (concentration of $\mathrm{F}^{-}$in rainwater is $25-50 \mu \mathrm{mol} / \mathrm{L}$ ). Apart from the burning of coal fluorine has a variety of industrial sources such as in the electrolysis of aluminum. Even the production of bricks and tiles from clays with high $\mathrm{F}^{-}$content is suspected to contribute substantially to the pollution. Indeed, high local concentration of fluorine due to the burning of coal is well known to be the cause of endemic fluorosis in areas where year-round coal stoves are in use [see, e.g., Qin et al., 2009]. The situation is especially grave in Guizhou province where more than 10 million people were reported to suffer from skeletal and dental fluorosis [Finkelman et al., 1999]. The coal produced in Sichuan has a fluorine content of about 200 $\mathrm{mg} / \mathrm{kg}$, and can in some areas be three times higher than the world average of $80 \mathrm{mg} / \mathrm{kg}$ [Liu et al., 2006].

[33] In a rough estimation the coal consumption of $160 \mathrm{Mt}$ (Figure 5) in 2008 with $4 \%$ sulfur and $200 \mathrm{mgF}^{-} / \mathrm{kg}$ results in an average daily release of $53 \mathrm{kt} / \mathrm{d}_{\text {of }} \mathrm{SO}_{4}^{2-}$ and $88 \mathrm{t} / \mathrm{d}$ of $\mathrm{F}^{-}$. The average daily load estimated from our measurements today is $52 \mathrm{kt} / \mathrm{d}$ in excess of what Chen et al. [2002] calculated from the data for the years 1958-1990. Unfortunately, concentrations of $\mathrm{F}^{-}$from the time before 1990 were not available, but assuming that all $\mathrm{F}^{-}$set free from coal 
Table 1. Total and Particulate Annual Loads of Elements in the Yangtze River at Datong (kt/yr)

\begin{tabular}{|c|c|c|c|c|c|}
\hline & $\begin{array}{l}\text { Total } \\
\text { Load }\end{array}$ & $\begin{array}{c}\text { Particulate } \\
\text { Load }\end{array}$ & 1958-1990 & $\begin{array}{l}\text { Total } \\
\text { Load }\end{array}$ & $\begin{array}{c}\text { Particulate } \\
\text { Load } \\
2000 / 01\end{array}$ \\
\hline Reference & this study & this study & $\begin{array}{c}\text { Chen et al. } \\
\text { [2002] }\end{array}$ & $\begin{array}{l}\text { Zhang } \\
{[1995]^{\mathrm{a}}}\end{array}$ & $\begin{array}{l}\text { Qiao et al. } \\
{[2007]^{\mathrm{b}}}\end{array}$ \\
\hline $\mathrm{Na}^{+}$ & 9760 & & & & \\
\hline $\mathrm{K}^{+}$ & 2260 & & 4500 & & \\
\hline $\mathrm{Mg}^{2+}$ & 6440 & & 5700 & & \\
\hline $\mathrm{Ca}^{2+}$ & 30,000 & & 27,000 & & \\
\hline $\mathrm{SO}_{4}^{2-}$ & 29,600 & & 10,700 & & \\
\hline $\mathrm{Cl}^{-}$ & 11,800 & & 3800 & & \\
\hline $\mathrm{F}^{-}$ & 177 & & & & \\
\hline DIC & 19,440 & & 20,000 & & $19,500^{\mathrm{c}}$ \\
\hline DOC & 1790 & & & & \\
\hline As & 3.10 & 0.82 & & & $1.76^{\mathrm{d}}$ \\
\hline B & 20.0 & 2.41 & & & \\
\hline $\mathrm{Ba}$ & 60.7 & 17.4 & & & 123 \\
\hline $\mathrm{Cd}$ & 0.085 & 0.054 & & 0.164 & \\
\hline Co & 0.99 & 0.94 & & 9.50 & \\
\hline $\mathrm{Cr}$ & 3.99 & 3.62 & & 61.2 & \\
\hline $\mathrm{Cu}$ & 5.95 & 3.84 & & 32.8 & 14.2 \\
\hline $\mathrm{Fe}$ & 2160 & 2140 & & 25,928 & \\
\hline K & 2540 & 714 & & & \\
\hline $\mathrm{Li}$ & 5.61 & 2.36 & & & \\
\hline $\mathrm{Mn}$ & 50.6 & 47.8 & & 555 & \\
\hline Mo & 1.01 & 0.06 & & & \\
\hline $\mathrm{Ni}$ & 3.49 & 2.58 & & 62.1 & 9.5 \\
\hline $\mathrm{Sb}$ & 0.76 & 0.05 & & & \\
\hline $\mathrm{Se}$ & 0.48 & 0.04 & & & $0.39^{\mathrm{d}}$ \\
\hline $\mathrm{Sr}$ & 161 & 4.53 & & & 22.1 \\
\hline $\mathrm{Pb}$ & 3.81 & 3.46 & & 25.1 & 21.5 \\
\hline $\mathrm{Zn}$ & 24.5 & 12.0 & & 60.2 & 58.5 \\
\hline $\mathrm{U}$ & 0.61 & 0.10 & & & \\
\hline $\mathrm{V}$ & 5.52 & 4.22 & & & 28.1 \\
\hline
\end{tabular}

${ }^{\mathrm{a}}$ The data by Zhang [1995] originates from five cruises in the Yangtze estuary between 1984 and 88 .

${ }^{\mathrm{b}}$ The data of Qiao et al. [2007] consists of two campaigns in November 2000 and May 2001. The particulate element contents published by Qiao et al. [2007] were multiplied with the annual averaged particle load at Datong given in this paper for the years 2000-2004.

${ }^{\mathrm{c}}$ Data by Liu and Shen [2001] for the period 1963-99.

${ }^{\mathrm{d}}$ Data by Yao et al. [2007] for total As and total Se.

burning ended up in the water it would make up $18 \%$ of today's load of $485 \mathrm{t} / \mathrm{d}$ (Table 1).

[34] $\mathrm{Na}^{+}$and $\mathrm{Cl}^{-}$originate from the weathering of rocks and the dissolution of evaporites but are also released to surface waters by industrial processes and household wastewater. The annual $\mathrm{Cl}^{-}$load has tripled since the measurements of Chen et al. [2002] (see Table 1). Substantially higher $\mathrm{Cl}^{-}$concentrations compared to earlier measurements by Chen et al. [2002] was also observed by Chetelat et al. [2008] with a decreasing trend downstream the Yangtze main channel. In our earlier investigation on the Yangtze in November 2006 where we sampled 21 locations on the way between the TGD and Shanghai [Müller et al., 2008], we did not observe any trend in the concentrations of $\mathrm{Cl}^{-}$or $\mathrm{Na}^{+}$, which indicated sources above the TGD. Chetelat et al. [2008] estimated that evaporites contributed about $45 \mu \mathrm{mol} / \mathrm{L} \mathrm{Cl}^{-}$, which would make about $1450 \mathrm{kt} / \mathrm{yr}$, or $12 \%$ of the present load. Thus, the threefold increase in $\mathrm{Cl}^{-}$and the similar increase in the sum of $\mathrm{Na}^{+}$and $\mathrm{K}^{+}$(Table 1) must be caused by human activities.

\subsection{The Nutrients $\mathrm{Si}, \mathrm{P}$, and $\mathrm{N}$}

[35] The concentrations of nutrients, and specially their ratios, have changed remarkably in the past 30 years. The consequence of the changes of the loads are decreasing Si:Nand increasing N:P-ratios, which most probably are one of the responsible factors for the increased occurrence of Harmful Algal Blooms (HABs) in the East China Sea [Duan et al., 2007; Li et al., 2007; Chai et al., 2009].

\subsubsection{Silica}

[36] Although according to Figure S2a the concentration of silica $\left(\mathrm{SiO}_{2}\right)$, an element of purely geogenic origin, is seemingly unaffected by the seasons, a closer view indicates a slight trend to somewhat higher concentration with increasing river water temperatures in summer (see Figure S2a and Table S1 in the auxiliary material). On the one hand, considering only chemical aspects this could be caused by the increasing solubility of silicates with increasing temperature. On the other hand, nearly constant $\mathrm{SiO}_{2}$ concentrations throughout the year suggest that removal of $\mathrm{SiO}_{2}$ by sestonic and planktic diatoms in reservoirs is difficult to detect. Indeed, Li et al. [2007] estimated the reduction of the dissolved Si load at Datong due to retention in reservoirs with a model to $13 \%$ for 2002 . Considering that annual loads strongly depend on annual water discharge rates, the $\mathrm{SiO}_{2}$ load estimated for 2009/2010 agreed well with estimates from earlier periods (Table 2). Dai et al. [2011], however, detected a decrease of dissolved silica until the 1970s and a relatively constant annual load of about $2080 \mathrm{kt} / \mathrm{yr}$, which is $820 \mathrm{kt} / \mathrm{yr}$ less than what we estimated (Table 2). A long-term decrease of dissolved silica loads as diagnosed also by Duan et al. [2007] and Li et al. [2007] can only be detected by means of monitoring data that extend over several decades.

\subsubsection{Phosphorus}

[37] Total Phosphorus (TP) concentrations tended to decrease with increasing water discharge approaching an about constant concentration at high water discharge (all

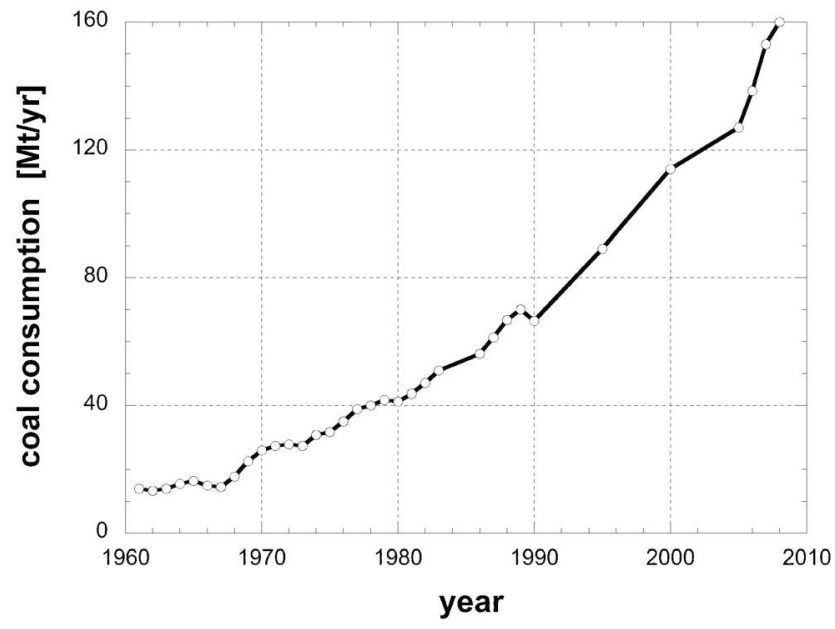

Figure 5. Coal consumption of Sichuan Province. Data until 1989 were taken from Chen et al. [2002] citing the National Bureau of Statistics of China [1991], and data since 1990 were taken from the National Bureau of Statistics of China [2009]. 


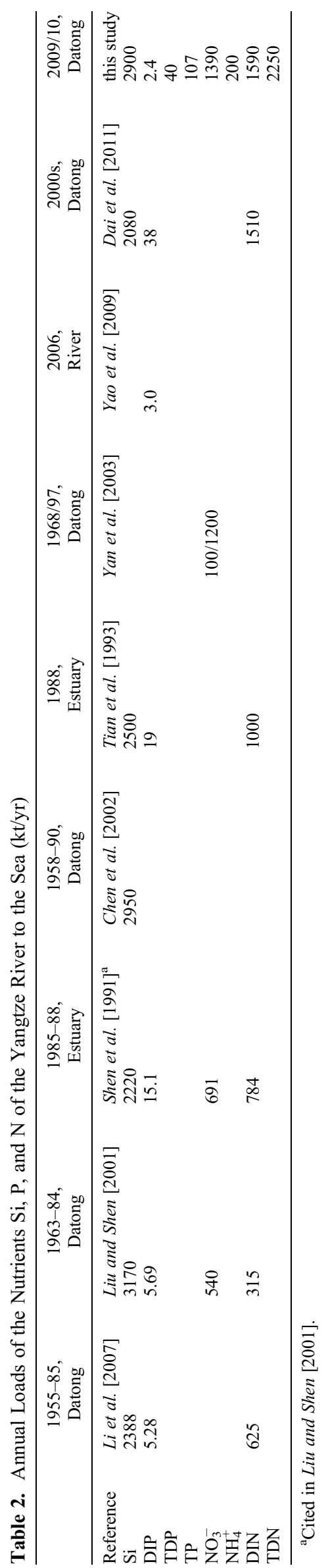

$\mathrm{P}$ and $\mathrm{N}$ measurements are listed in Table $\mathrm{S} 2$ in the auxiliary material). Two thirds of TP were transported in the particulate fraction. Concentrations of DIP were unusually low for river water varying in the range of $1-6 \mu \mathrm{gP} / \mathrm{L}$ (Figure S1e). This can be attributed to the high affinity of DIP to soil derived suspended particles relatively rich in Fe-oxides that seemingly buffer the DIP concentration at this low level. The concentrations of TDP were quite constant at $36-52 \mu \mathrm{gP} / \mathrm{L}$ during the seasons independent of the greatly varying water discharge, except for two peaks during the dry season. The sorbed DIP may desorb when the particle suspension is diluted [Müller et al., 2006], which is indicated by, and may explain, the much higher DIP loads determined in the estuary region by Shen et al. [1991], cited in Liu and Shen, [2001] and Tian et al. [1993] listed in Table 2. Determination of TDP comprises organically bound $\mathrm{P}$ which becomes bio-available by mineralization but still does not include the fraction of desorbable P from the particulate matter. Hence, the amount of bio-available $\mathrm{P}$ relevant for primary production in the sea lies somewhere between the estimates for TDP and TP.

\subsubsection{Nitrogen}

[38] Similar to TP concentrations also $\mathrm{NO}_{3}^{-}$, TDN, and $\mathrm{NH}_{4}^{+}$tended to decrease during the time of high water discharge and to increase in the months of low flow. Apart from mineralization of natural organic matter, $\mathrm{NH}_{4}^{+}$has no significant natural sources and is expected to decrease with increasing $\mathrm{Q}$, in a mere dilution process. The loads of $\mathrm{NH}_{4}^{+}$ spread between 300 and $600 \mathrm{tN} / \mathrm{d}$. For DOC we estimated an annual load of $1.8 \mathrm{Mt}$.

[39] In contrast to the Si load, large increase in the load of dissolved inorganic nitrogen (DIN) is apparent. This fact has been discussed by the authors cited in Table 2 and is mainly related to the excessive use of nitrogen fertilizers since 1978 (Figure 6). The consumption of $\mathrm{N}$ fertilizers almost doubled in the subsequent three years [Duan et al., 2007]. Zhang et al. [1999] diagnosed a doubling of the

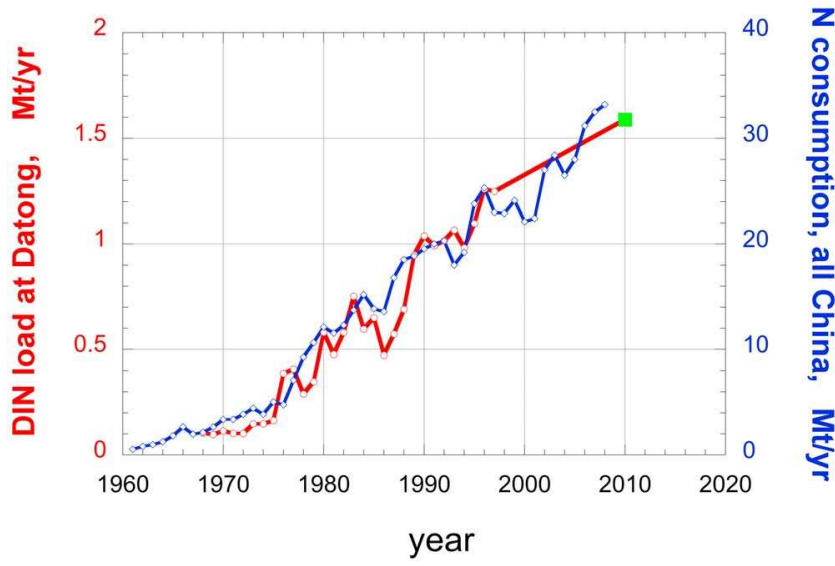

Figure 6. Annual load of DIN at Datong Hydrological Station. Data from 1968 to 1997 extracted from Yan et al. [2003] (red line), extended by the estimate of this study (green square). The blue line depicts the consumption of $\mathrm{N}$ fertilizers over all China in Mt/yr as reported in FAOSTAT (www.fao.org). 
DIN concentration in the Yangtze from 1980 to 1997 at Nantong. Long-term monitoring data from the hydrographic station at Datong (Figure 6) made available by Yan et al. [2003] show that the DIN load today has increased by a factor of 15 compared to the early measurements at around 1970. Dai et al. [2011] as well analyzed a DIN load very similar to our estimate. The amount of bio-available nitrogen may be even higher and rather correspond to the estimate for TDN $(2.25 \mathrm{Mt} / \mathrm{yr})$ than to DIN.

\subsection{Mineralization of Organic Matter}

[40] The concentration of oxygen varied inversely proportional with the water temperature and was always about $10-$ $20 \%$ (av. 15\%) below maximum saturation during the whole year (Figure 7a). A parallel trend was observed for $\mathrm{CO}_{2}$ as well, however, $\mathrm{CO}_{2}$ in the river was always 2-6 times higher than the equilibrium with the atmosphere. This pattern may originate from the quasi-steady state process of the mineralization of organic matter carried by the river where $\mathrm{O}_{2}$ is consumed and $\mathrm{CO}_{2}$ produced proportionally. The rate of organic carbon mineralization can be estimated from both profiles independently. The method of calculation is explained in the Methods section.

[41] Similar to Devol et al. [1995] in their study on the mineralization of organic matter in the Amazon we assumed that respiration is the primary process for the consumption of oxygen in the river, and that exchange of $\mathrm{O}_{2}$ and $\mathrm{CO}_{2}$ with the atmosphere is at steady state. Photosynthesis in the turbid waters of the Yangtze was neglected, and we assume that the flux of $\mathrm{O}_{2}$ into the river water equals the mineralization rate of organic matter.

[42] In proportion to the organic matter mineralized in the river, $\mathrm{CO}_{2}$ is produced, which adds to the $\mathrm{CO}_{2}$ that infiltrates with groundwater and evades via the water-air interface. Thus, $\mathrm{pCO}_{2}$ in a river that carries organic matter and/or is affected by groundwater inflows is always higher than the $\mathrm{pCO}_{2}$ of the atmosphere. The influence of groundwater $\mathrm{CO}_{2}$ in the Yangtze River may be small compared to the mineralization of organic matter due to the heavy channeling of the river, cut-off from floodplains, kolmation of the river bed, and the high surface water discharge. In a steady state situation, where the rate of production of $\mathrm{CO}_{2}$ is equal to the loss rate to the atmosphere, all carbonate equilibria in the river adjust according to the prevailing $\mathrm{pCO}_{2}$, which can then be estimated from the analytically easily accessible parameters $\mathrm{pH}$ and alkalinity.

[43] Figure $7 \mathrm{~b}$ depicts the fluxes of $\mathrm{O}_{2}$ from the atmosphere to the river and $\mathrm{CO}_{2}$ from the river to the atmosphere during the year of sampling, as well as the water discharge and temperature. The flux of $\mathrm{O}_{2}$ varies between $120 \mathrm{mmol}$ $\mathrm{m}^{-2} \mathrm{~d}^{-1}$ and $460 \mathrm{mmol} \mathrm{m} \mathrm{m}^{-2} \mathrm{~d}^{-1}$ but neither water discharge nor temperature appear to be responsible for the variation. The flux of $\mathrm{CO}_{2}$ is anti-correlated to the flux of $\mathrm{O}_{2}$ and ranges from $100 \mathrm{mmol} \mathrm{m}^{-2} \mathrm{~d}^{-1}$ to $280 \mathrm{mmol} \mathrm{m} \mathrm{m}^{-1}$. The amount of organic carbon that is mineralized daily (Figure 7c) agrees relatively well from the estimations of both, $\mathrm{O}_{2}$ and $\mathrm{CO}_{2}$. It varies seasonally and tends to follow the water discharge between around $200 \mathrm{t} / \mathrm{d}$ at low flow (December) and around $1100 \mathrm{t} / \mathrm{d}$ at high flow (June/July). Mineralization rates related to volumes are $0.11 \mathrm{gC} \mathrm{m}^{-3}$ at low flow and $0.35 \mathrm{gC} \mathrm{m}^{-3}$ at high flow. The good agreement of the two estimates suggests that the major fraction of organic matter mineralization leading to the increased $\mathrm{pCO}_{2}$ in the river occurs within the river itself and only a fraction that cannot be distinguished with the method applied originated from other sources such as groundwater infiltration.

[44] The Yangtze River was saturated with respect to calcite within the analytical error $\left( \pm 5 \%\right.$ for $\mathrm{Ca}^{2+}$ and alkalinity, and \pm 0.1 for $\mathrm{pH}$ ), except for three values between August and October 2009 that were around three. The concentrations of both, alkalinity and $\mathrm{Ca}^{2+}$, are high compared to other large rivers of the world. Such high concentrations can only be attained when the calcite is exposed to water of a high partial pressure of $\mathrm{CO}_{2}$. Stumm and Morgan [1996, p. 189] have illustrated the relationship between alkalinity and $\mathrm{Ca}^{2+}$ for a variety of large world rivers. The increasing $\mathrm{pCO}_{2}$ causing the increasing concentrations of the species of the carbonate system is interpreted with increasing amounts of degradable organic matter carried by the rivers. Our value for the Yangtze is among the highest worldwide.

\subsection{Trace Elements}

[45] Even though concentrations of most trace elements in the Yangtze River are in the same range as in other large rivers of the world [Müller et al., 2008], loads are enormous due to the high water discharge. We estimated annual loads from our data set using the measurements from July 2009 to June 2010. It is difficult to assess the changes of the recent decades due to the scarcity of studies available in the English literature. Results and additional literature data are presented in Table 1, while measured concentrations are given in Tables S3-S5 in the auxiliary material.

[46] Trends in the concentrations of trace elements associated with suspended particles during the sampling period was not correlated with water discharge, precipitation, or temperature. Particulate metal concentrations were highest during July to October when water discharge was high and decreasing (Table S4 in the auxiliary material). Contents were lowest the following year in springtime (April to June) during the increasing branch of the water discharge. They appeared to change independent from hydrological and seasonal processes.

[47] For comparison we depict in Figure 8 contents analyzed in uncontaminated sediments sampled in 1987/88 in the source areas of the Yangtze [Zhang and Zhou, 1992], from the estuary 1984-88 [Zhang, 1995], at Datong 2000/01 [Qiao et al., 2007], Wuhan [Yang et al., 2009], and averages over the whole river [Song et al., 2010]. The similarity of the metal content of the particles in spite of the different times, locations and origins are striking. The range of trace element contents we observed during 14 months of sampling varied by factors of 3-6. The highest contents all exceeded the quality targets recommended by the EC (Overview of quality standards of the $\mathrm{EC}$, international river basin communities, and LAWA for heavy metals, 2006, http://www.umweltbundesamt.de/wasser-e/ themen/fluesse-und-seen/fluesse/bewertung/ow_s2_2.htm) by up to a factor of two (for data of Figure 8 see Table S7 in the auxiliary material).

[48] The most rigorous way for the assessment of anthropogenic contamination is the determination of enrichment factors for trace elements associated with suspended particles [see, e.g., Meybeck et al., 2004]. The enrichment factor or 

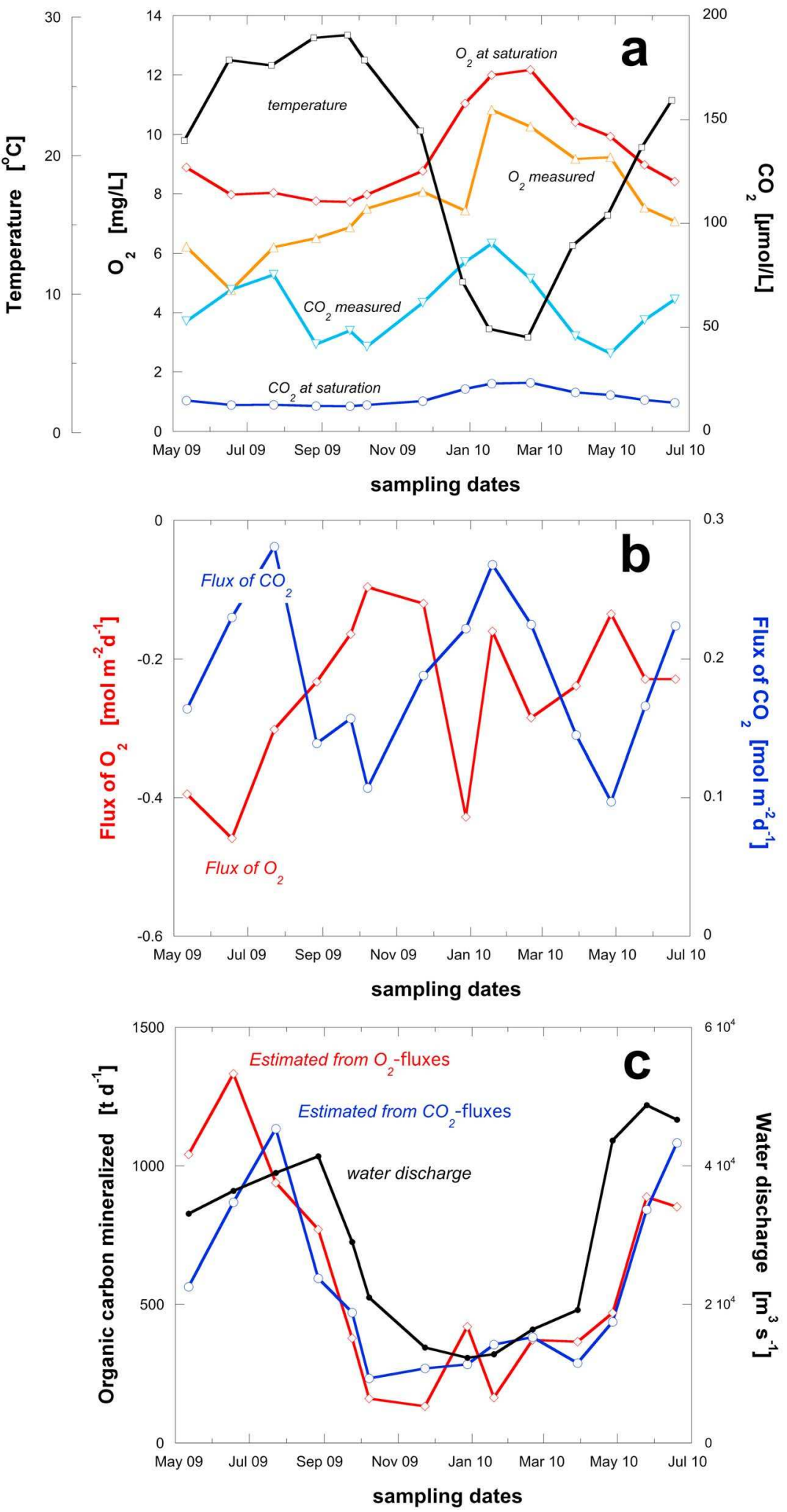

Figure 7. Mineralization of organic matter estimated from $\mathrm{O}_{2}$ consumption and $\mathrm{CO}_{2}$ production. (a) Concentrations of measured $\mathrm{O}_{2}$ (orange) and $\mathrm{CO}_{2}$ (light blue), and calculated $\mathrm{O}_{2}$ (red) and $\mathrm{CO}_{2}$ (dark blue) at equilibrium with the atmosphere depending on temperature and partial pressure. The black line depicts temperature. (b) Fluxes of $\mathrm{O}_{2}$ and $\mathrm{CO}_{2}$ across the water-atmosphere interface in mol m $\mathrm{m}^{-2} \mathrm{~d}^{-1}$. (c) Estimated mineralization rates of organic carbon from fluxes of $\mathrm{O}_{2}$ (red) and $\mathrm{CO}_{2}$ (blue) in $\mathrm{tC} \mathrm{d}^{-1}$. The black line depicts water discharge. 


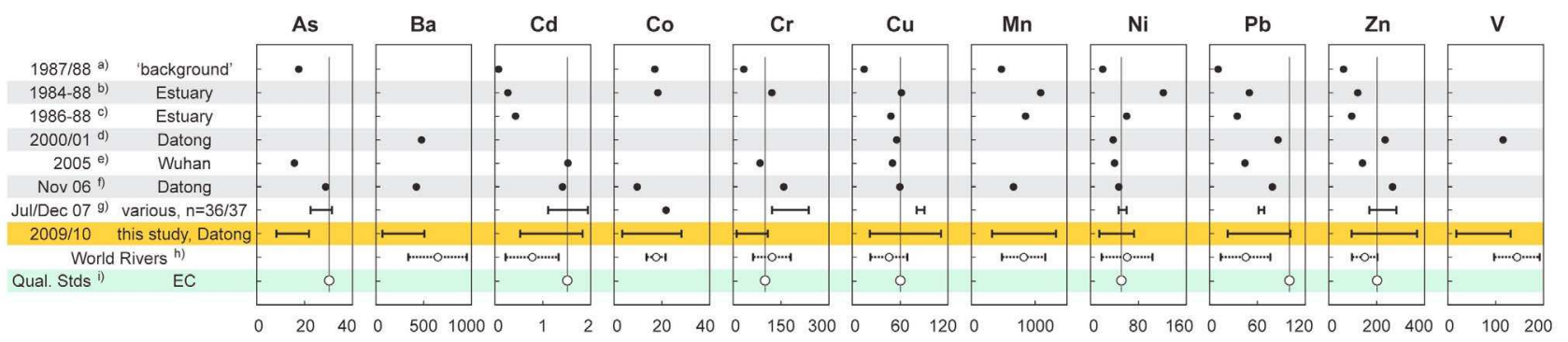

Figure 8. Trace metal contents of particles in $\mu \mathrm{g} / \mathrm{g}$ collected from the Yangtze River at different times and different locations (see text). World river averages are calculated from the compilation by Gaillardet et al. [1999]. The last line contains quality target values recommended by the EC.

pollution index (PI) describes how much an element is enriched with regard to its 'natural background' concentration:

$$
P I=\frac{M e_{\text {sample }}-\text { Me background }}{M e_{\text {background }}}
$$

Of course, it is difficult to determine a natural background for a river with such an enormous catchment area and such scarce measurements available. The most suited study to our knowledge is the one by Zhang and Zhou [1992] who published high quality trace metal measurements from suspended particles of a stream in the source region of the Yangtze. The most prominent elements for the assessment of anthropogenic pollution are $\mathrm{Cd}, \mathrm{Cu}, \mathrm{Pb}, \mathrm{Zn}$, and $\mathrm{Hg}$ [Meybeck et al., 2004]. The sum of the PIs of these elements are suggested to be used for a combined metal pollution index, however, as measurements of $\mathrm{Hg}$ are missing in our data set, we discuss the PIs of the individual elements (Table 3). Pollution indices calculated for the annual average concentrations of the Yangtze at Datong were $7.0(\mathrm{Cd})$, $0.7(\mathrm{Cr}), 2.9(\mathrm{Cu}), 1.2(\mathrm{Ni}), 5.0(\mathrm{~Pb})$, and $2.7(\mathrm{Zn})$. A correlation between water discharge and PI as described by Meybeck et al. [2004] who observed highest PI values during the low flow period was not detected. A temporal trend is not evident from a comparison with data from Zhang et al. [1990] (sampled in 1984), and Qiao et al. [2007] (sampled 2000/01) except for a much higher value for $\mathrm{Cd}$ and a decrease of the PI of Cr. Recently, Song et al. [2010] reported data on 37 suspended sediment samples along the main channel of the river, which are higher in $\mathrm{Cd}, \mathrm{Cr}$, and $\mathrm{Cu}$ than our measurements, but very similar in $\mathrm{Ni}, \mathrm{Pb}$, and $\mathrm{Zn}$. The values may not be directly comparable since the River upstream is locally more contaminated with trace elements than downstream. These authors point out the three mining areas Panzhihua, Northeast Yunan, and Nanling as the main sources of trace element contamination of the Yangtze. The effect of these sources may, however, be attenuated at Datong due to the many reservoirs along the main channel of the Yangtze - most of all the TGD - and the Poyang lake acting as sedimentation basins where trace elements are removed by scavenging.

[49] Even though the trace element contents of the suspended particulate matter has not changed much overall, the loads transported to the sea have greatly decreased (Table 1). Particulate loads of all trace elements determined by Qiao et al. [2007] from samples of 2000/01 were 73-86\% smaller (As: $50 \%$ ) in our sampling campaign nine years after
(2009/10). This decrease of trace metal loads matches the decrease of the suspended particle load (76\%) as Qiao et al. [2007] estimated an average annual particle load of $250 \mathrm{Mt}$ for the years 2000-04. This indicates that the decrease of the trace element load is mainly caused by the retention of suspended particles in the many reservoirs and thus by the decrease of the particle transport in recent years, but not by an effective decrease of emission to the river.

[50] The decrease of the metal loads may be partly influenced by efforts of the Chongqing regional government to relocate metal polluting industries out of the urban area in the past decade. Due to the lack of detailed information it is not possible to evaluate or quantify the effect of such actions.

[51] Hence, we conclude that the high input of trace elements to the river is not reflected in high metal contents of the suspended particles and thus high discharge to the East China Sea. As a large fraction of trace elements are transported associated with suspended particulate matter it shares the fate of the particles that settle in the many reservoirs and dams, particularly the TGD, which reduced the particle transport of the Yangtze by more than $400 \mathrm{Mt} / \mathrm{yr}$. Sediments in these locations are probably bearing the 'missing' loads of metals and may become local hot spots for contamination.

\section{Conclusions}

[52] Water quality of the Yangtze River is an essential and effective indicator on natural processes as well as anthropogenic activities in the catchment. On the one hand quantification and long-term monitoring of inorganic water constituents allows tracing variations attributable to changes

Table 3. Estimation of Pollution Index for Anthropogenic Trace Metals $^{\mathrm{a}}$

\begin{tabular}{|c|c|c|c|c|c|}
\hline \multirow{2}{*}{\multicolumn{2}{|c|}{$\begin{array}{c}\text { Natural } \\
\text { Background (mg/kg) } \\
\text { [Zhang and Zhou, } \\
\text { 1992] }\end{array}$}} & \multicolumn{4}{|c|}{ PI } \\
\hline & & This Study & $\begin{array}{c}\text { Zhang et al. } \\
\text { [1990] }\end{array}$ & $\begin{array}{c}\text { Qiao et al. } \\
\text { [2007] }\end{array}$ & $\begin{array}{c}\text { Song et al. } \\
{[2010]}\end{array}$ \\
\hline $\mathrm{Cd}$ & 0.12 & 7.0 & 1.6 & - & 11.3 \\
\hline $\mathrm{Cr}$ & 36.0 & 0.7 & 2.4 & 2.3 & 4.1 \\
\hline $\mathrm{Cu}$ & 17.4 & 2.9 & 2.6 & 2.3 & 4.0 \\
\hline $\mathrm{Ni}$ & 21.0 & 1.2 & 4.9 & 0.8 & 1.6 \\
\hline $\mathrm{Pb}$ & 10.9 & 5.0 & 3.6 & 6.9 & 5.0 \\
\hline $\mathrm{Zn}$ & 61.5 & 2.7 & 1.0 & 2.8 & 2.7 \\
\hline
\end{tabular}

${ }^{\mathrm{a}}$ Data by Song et al. [2010] were averaged from 36 samples along the whole main channel. 
in hydrology, precipitation, temperature, natural weathering, seasonal periodicity or to any aspects of climate change. On the other hand anthropogenic activities affecting surface and groundwater, soil and the atmosphere become apparent, such as changes in the hydrological water discharge and particle transport, enhancement of element cycles, e.g., by mining or excessive coal burning, agricultural practices, and waste disposal.

[53] The most significant change in the last decades is the marked decrease of the load of suspended particles in the Yangtze River that is caused by the excessive construction of reservoirs. An increasing number of publications report on the changing loads of nutrients, mainly $\mathrm{Si}, \mathrm{N}$, and $\mathrm{P}$. These elements become more relevant for primary production as the river becomes more lake characteristics. They are, however, essential for the shelf region of the East China Sea where an increase of Harmful Algal Blooms (HABs) with ever more dangerous species was recorded in recent years.

[54] Comparison with our load estimations of trace elements with older data from the literature shows that loads to the East China Sea have decreased in the past decade. Trace metal contents of particulate matter published by various authors, however, are of similar orders of magnitudes. Therefore, the decreasing loads are at least partly attributed to the decreased load of suspended particles. Thus the load of trace elements settled in reservoirs should be estimated. However, few English publications are available on trace element measurements in the Yangtze River, hence, the loads estimated of earlier years are subject to large uncertainty.

[55] The detailed analysis of patterns, concentrations and loads of inorganic water constituents allow the detection and quantification of interesting facts and reflect major activities in the catchment. It reveals, however, that they alone are not responsible for the destruction of the river ecosystem of the middle and lower Yangtze, which is manifested in the disappearance of species abundance and fishing yields.

[56] Acknowledgments. We are indebted to Hongliang Sha, Jinping Wu, Guochang Zhang, and colleagues from the Datong Hydrological Station of the Hydrology Bureau of the Changjiang Water Resources Commission for samples collection. Alfred Wüest made valuable comments to the manuscript and helped to estimate the size fraction of suspended particles. Martin Schmid helped with the estimation of gas exchange. René Gächter is acknowledged for critical discussions and improvement of the manuscript. The critical comments of one reviewer greatly helped to accomplish the manuscript. The project was supported by the External Cooperation Program of the Chinese Academy of Sciences, grant GJHZ0908, and by the Sino-Swiss Science and Technology Cooperation Program of the Swiss National Science Foundation, project IZL CZ2 123912

\section{References}

Alin, S. R., M. F. L. Rasera, C. I. Salimon, J. E. Richey, G. W. Holtgrieve, A. V. Krusche, and A. Snidvongs (2011), Physical controls on carbon dioxide transfer velocity and flux in low-gradient river systems and implications for regional carbon budgets, J. Geophys. Res., 116, G01009, doi:10.1029/2010JG001398.

Anderson, D. M. (2009), Approaches to monitoring, control and management of harmful algal blooms (HABs), Ocean Coastal Manage., 52, 342-347, doi:10.1016/j.ocecoaman.2009.04.006.

Bao, X., M. Watanabe, Q. Wang, S. Hayashi, and J. Liu (2006), Nitrogen budgets of agricultural fields of the Changjiang River basin from 1980 to 1990, Sci. Total Environ., 363, 136-148, doi:10.1016/j.scitotenv.2005.06.029.

Benson, B. B., and D. Krause Jr. (1980), The concentration and isotopic fractionation of gases dissolved in freshwater inequilibrium with the atmosphere. 1. Oxygen, Limnol. Oceanogr., 25(4), 662-671, doi:10.4319/ 10.1980.25.4.0662.

Berkoff, J. (2003), China: The South-North Water Transfer Project-Is it justified? Water Policy, 5, 1-28.
Chai, C., Z. Yu, Z. Shen, X. Song, X. Cao, and Y. Yao (2009), Nutrient characteristics in the Yangtze River Estuary and the adjacent East China Sea before and after impoundment of the Three Gorges Dam, Sci. Total Environ., 407, 4687-4695, doi:10.1016/j.scitotenv.2009.05.011.

Chen, J., F. Wang, X. Xia, and L. Zhang (2002), Major element chemistry of the Changjiang (Yangtze River), Chem. Geol., 187, 231-255, doi:10.1016/S0009-2541(02)00032-3.

Chen, X. Q., Y. X. Yan, R. S. Fu, X. P. Dou, and E. F. Zhang (2008), Sediment transport from the Yangtze River, China, into the sea over the post-Three Gorge Dam period: A discussion, Quat. Int., 186, 55-64, doi:10.1016/j.quaint.2007.10.003

Chen, Z. Y., Y. Saito, Y. Kanai, T. Y. Wei, L. Q. Li, H. S. Yao, and Z. H. Wang (2004), Low concentration of heavy metals in the Yangtze estuarine sediments, China: A diluting setting, Estuarine Coastal Shelf Sci., 60, 91-100, doi:10.1016/j.ecss.2003.11.021.

Chetelat, B., C. Q. Liu, Z. Q. Zhao, Q. L. Wang, S. L. Li, J. Li, and B. L. Wang (2008), Geochemistry of the dissolved load of the Changjiang Basin rivers: Anthropogenic impacts and chemical weathering, Geochim. Cosmochim. Acta, 72(17), 4254-4277, doi:10.1016/j.gca.2008.06.013.

Chibamba, D., J. Li, and L. Zhang (2009), Land use planning and the Yangtze ecosystem (Wuhan section): Implications for sustainability, J. Environ. Sci. Technol., 2(1), 1-11, doi:10.3923/jest.2009.1.11.

China Three Gorges Project Corporation (2007), Annual report, Beijing. [Available at http://www.ctgpc.com.cn/en/file/Annual Report 2007.pdf] Cui, J., S. An, Z. Wang, C. Fang, Y. Liu, H. Yang, Z. Xu, and S. Liu (2009), Using deuterium excess to determine the sources of high-altitude precipitation: Implications in hydrological relations between sub-alpine forests and alpine meadows, J. Hydrol., 373, 24-33, doi:10.1016/j. jhydrol.2009.04.005.

Dai, Z. J., J. Z. Du, X. L. Zhang, N. Su, and J. F. Li (2011), Variation of riverine material loads and environmental consequences on the Changjiang (Yangtze) estuary in recent decades (1955-2008), Environ. Sci. Technol., 45, 223-227, doi:10.1021/es103026a.

Dansgaard, W. (1964), Stable isotopes in precipitation, Tellus, 16, 436-468, doi:10.1111/j.2153-3490.1964.tb00181.x.

Datta, D. K., L. P. Gupta, and V. Subramanian (2000), Dissolved fluoride in the Lower Ganges-Brahmaputra-Meghna River system in the Bengal Basin, Bangladesh, Environ. Geol., 39(10), 1163-1168, doi:10.1007/ s002549900094.

Deutsches Institut für Normung (2002), German Standard Methods for the Examination of Water, Wastewater and Sludge [in German], Wiley VCH, Weinheim.

Devol, A. H., B. R. Forsberg, J. E. Richey, and T. P. Pimentel (1995), Seasonal variation in chemical distributions in the Amazon (Solimoes) River: A multiyear time series, Global Biogeochem. Cycles, 9(3), 307-328, doi:10.1029/95GB01145.

Duan, L., X. X. Ma, T. Larssen, J. Mulder, and J. M. Hao (2011), Response of surface water acidification in Upper Yangtze River to $\mathrm{SO}_{2}$ emissions abatement in China, Environ. Sci. Technol., 45, 3275-3281, doi:10.1021/es 1038672

Duan, S. W., F. Xu, and L. J. Wang (2007), Long-term changes in nutrient concentrations of the Changjiang River and principal tributaries, Biogeochemistry, 85, 215-234, doi:10.1007/s10533-007-9130-2.

Dudgeon, D. (2010), Requiem for a river: Extinctions, climate change and the last of the Yangtze, Aquat. Conserv. Mar. Freshwater Ecosyst., 20, 127-131, doi:10.1002/aqc.1098.

Finkelman, R. B., H. E. Belkin, and B. Zheng (1999), Health impacts of domestic coal use in China, Proc. Natl. Acad. Sci. U. S. A., 96, 3427-3431, doi:10.1073/pnas.96.7.3427.

Gaillardet, J., B. Dupré, and C. J. Allègre (1999), Geochemistry of large river suspended sediments: Silicate weathering or recycling tracer?, Geochim. Cosmochim. Acta, 63(23-24), 4037-4051, doi:10.1016/S00167037(99)00307-5.

Gao, C. L., H. Q. Yin, N. S. Ai, and Z. W. Huang (2009), Historical analysis of $\mathrm{SO}_{2}$ pollution control policies in China, Environ. Manage., 43 447-457, doi:10.1007/s00267-008-9252-x.

Jiang, Y. (2009), China's water scarcity, J. Environ. Manage., 90, 3185-3196, doi:10.1016/j.jenvman.2009.04.016.

$\mathrm{Ju}, \mathrm{X}$., et al. (2009), Reducing environmental risk by improving $\mathrm{N}$ management in intensive Chinese agricultural systems, Proc. Natl. Acad. Sci. U. S. A., 106(9), 3041-3046, doi:10.1073/pnas.0813417106.

Kahrl, F., Y. Li, Y. Su, T. Tennigkeit, A. Wilkes, and J. Xu (2010), Greenhouse gas emissions from nitrogen fertilizer use in China, Environ. Sci. Policy, 13, 688-694, doi:10.1016/j.envsci.2010.07.006.

Larssen, T., H. M. Seip, A. Semb, J. Mulder, I. P. Muniz, R. D. Vogt, E. Lydersen, V. Angell, T. Dagang, and O. Eilertsen (1999), Acid deposition and its effects in China: An overview, Environ. Sci. Policy, 2, 9-24, doi:10.1016/S1462-9011(98)00043-4 
Larssen, T., et al. (2006), Acid rain in China, Environ. Sci. Technol., 40(2), 418-425, doi:10.1021/es0626133.

Li, M. T., K. Q. Xu, M. Watanabe, and Z. Y. Chen (2007), Long-term variations in dissolved silicate, nitrogen, and phosphorus flux from the Yangtze River into the East China Sea and impacts on estuarine ecosystem, Estuarine Coastal Shelf Sci., 71(1-2), 3-12, doi:10.1016/j.ecss.2006.08.013.

Liu, D., Y. Sakai, M. Yamamoto, and M. Sadakata (2006), Behavior of fluorine in the combustion of Chinese coal in small furnaces, Energy Fuels, 20, 1406-1410, doi:10.1021/ef050326z.

Liu, X., and H. Shen (2001), Estimation of dissolved inorganic nutrients fluxes from the Changjiang River into estuary, Sci. China, Ser. B, 44, suppl. 1, 135-141.

Liu, Y., N. Fan, S. An, X. Bai, F. Liu, Z. Xu, Z. Wang, and S. Liu (2008a), Characteristics of water isotopes and hydrograph separation during the wet season in the Heishui River, China, J. Hydrol., 353, 314-321, doi:10.1016/j.jhydrol.2008.02.017.

Liu, Z., L. Tian, T. Yao, and W. Yu (2008b), Seasonal deuterium excess in Nagqu precipitation: Influence of moisture transport and recycling in the middle of Tibetan Plateau, Environ. Geol., 55, 1501-1506, doi:10.1007/ s00254-007-1100-4.

Livingstone, D. A. (1963), Chemical composition of rivers and lakes, U.S. Geol. Surv. Prof. Pap., 440-G.

Mao, C. P., J. Chen, X. Y. Yuan, Z. F. Yang, W. Balsam, and J. F. Ji (2010), Seasonal variation in the mineralogy of the suspended particulate matter of the lower Changjiang River at Nanjing, China, Clays Clay Miner., 58(5), 691-706, doi:10.1346/CCMN.2010.0580508.

Meybeck, M., and F. Moatar (2011), Daily variability of river concentrations and fluxes: Indicators based on the segmentation of the rating curve, Hydrol. Processes, 26, 1188-1207, doi:10.1002/hyp.8211.

Meybeck, M., A. J. Horowitz, and C. Grosbois (2004), The geochemistry of the Seine River Basin particulate matter: Distribution of an integrated metal pollution index, Sci. Total Environ., 328, 219-236, doi:10.1016/j. scitotenv.2004.01.024

Milliman, J. D., Q. Xie, and Z. Yang (1984), Transfer of particulate organic carbon and nitrogen from the Yangtze River to the ocean, Am. J. Sci. 284, 824-834, doi:10.2475/ajs.284.7.824.

Moosmann, L., B. Müller, R. Gächter, A. Wüest, E. Butscher, and P. Herzog (2005), Trend-oriented sampling strategy and estimation of soluble reactive phosphorus in streams, Water Resour. Res., 41, W01020, doi:10.1029/ 2004WR003539.

Müller, B., R. Stierli, and A. Wüest (2006), Phosphate adsorption by mineral weathering particles in oligotrophic waters of high particle content, Water Resour. Res., 42, W10414, doi:10.1029/2005WR004778.

Müller, B., M. Berg, Z. P. Yao, X. F. Zhang, D. Wang, and A. Pfluger (2008), How polluted is the Yangtze River? Water quality downstream from the Three Gorges Dam, Sci. Total Environ., 402, 232-247, doi:10.1016/j.scitotenv.2008.04.049.

National Bureau of Statistics of China (1991), China Energy Statistical Yearbook [in Chinese], China Stat. PressBeijing.

National Bureau of Statistics of China (2009), China Energy Statistical Yearbook [in Chinese], China Stat. Press, Beijing. [Available at http:// www.chinastatistics.net/china-energy-statistical-yearbook-2009-m-6.html]

Plummer, L. N., and E. Busenberg (1982), The solubilities of calcite, aragonite and vaterite in $\mathrm{CO}_{2}-\mathrm{H}_{2} \mathrm{O}$ solutions between 0 and $90^{\circ} \mathrm{C}$, and an evaluation of the aqueous model for the system $\mathrm{CaCO}_{3}-\mathrm{CO}_{2}-\mathrm{H}_{2} \mathrm{O}$, Geochim. Cosmochim. Acta, 46, 1011-1040, doi:10.1016/0016-7037(82)90056-4.

Qiao, S. Q., Z. S. Yang, Y. J. Pan, and Z. G. Guo (2007), Metals in suspended sediments from the Changjiang (Yangtze River) and Huanghe (Yellow River) to the sea, and their comparison, Estuarine Coastal Shelf Sci., 74(3), 539-548, doi:10.1016/j.ecss.2007.05.042.

Qin, X., S. Wang, M. Yu, L. Zhang, X. Li, Z. Zuo, X. Zhang, and L. Wang (2009), Child Skeletal Fluorosis from Indoor Burning of Coal in Southwestern China, J. Environ. Public Health, 2009, 969764, doi:10.1155/ 2009/969764

Rozanski, K., L. Aragaus, R. Gonfiantini, P. K. Swart, C. Lohmann Kyger, J. A. McKenzie, and S. Savin (1993), Isotopic patterns in modern global precipitation, in Climate Change in Continental Isotopic Records, Geophys. Monogr. Ser., vol. 78, edited by P. K. Swart et al., pp. 1-36, AGU, Washington, D. C., doi:10.1029/GM078p0001.

Shen, Z. L., T. X. Gu, and X. B. Xie (1991), Output nutrients fluxes from the Changjiang River [in Chinese], Mar. Sci., 11(6), 67.

Song, Y. X., J. F. Ji, C. P. Mao, Z. F. Yang, X. Y. Yuan, G. A. Ayoko, and R. L. Frost (2010), Heavy metal contamination in suspended solids of Changjiang River-Environmental implications, Geoderma, 159 286-295, doi:10.1016/j.geoderma.2010.07.020

Stumm, W., and J. J. Morgan (1996), Aquatic Chemistry, 3rd ed., Wiley Intersci., New York.

Tian, L., V. Masson-Delmotte, M. Stievenard, T. Yao, and J. Jouzel (2001), Tibetan Plateau summer monsoon northward extent revealed by measurements of water stable isotopes, J. Geophys. Res., 106, 28,08128,088, doi:10.1029/2001JD900186.

Tian, R. C., F. X. Hu, and A. Saliot (1993), Biogeochemical processes controlling nutrients at the turbidity maximum and the plume water fronts in the Changjiang estuary, Biogeochemistry, 19, 83-102, doi:10.1007/ BF00000797.

Tong, C. L., C. A. S. Hall, and H. Q. Wang (2003), Land use change in rice, wheat and maize production in China (1961-1998), Agric. Ecosyst Environ., 95(2-3), 523-536, doi:10.1016/S0167-8809(02)00182-2.

Turvey, S. T., et al. (2007), First human-caused extinction of a cetacean species?, Biol. Lett., 3, 537-540, doi:10.1098/rsb1.2007.0292.

Wang, B. D., X. L. Wang, and R. Zhan (2003), Nutrient conditions in the Yellow Sea and the East China Sea, Estuarine Coastal Shelf Sci., 58 , 127-136, doi:10.1016/S0272-7714(03)00067-2.

Wang, H., Z. Yang, Y. Wang, Y. Saito, and J. P. Liu (2008), Reconstruction of sediment flux from the Changjiang (Yangtze River) to the sea since the 1860s, J. Hydrol., 349, 318-332, doi:10.1016/j.jhydrol.2007.11.005.

Wang, Z., Y. Li, and Y. He (2007), Sediment budget of the Yangtze River, Water Resour. Res., 43, W04401, doi:10.1029/2006WR005012.

$\mathrm{Xu}, \mathrm{K}$., J. D. Milliman, Z. Yang, and H. Wang (2006), Yangtze sediment decline partly from Three Gorges dam, Eos Trans. $A G U, 87(19), 185$, doi:10.1029/2006EO190001.

Xu, K., J. D. Milliman, and H. Xu (2010), Temporal trend of precipitation and runoff in major Chinese Rivers since 1951, Global Planet. Change, 73, 219-232, doi:10.1016/j.gloplacha.2010.07.002.

Yamanaka, T., J. Shimada, Y. Hamada, T. Tanaka, Y. Yang, W. Zhang, and $\mathrm{C}$. $\mathrm{Hu}$ (2004), Hydrogen and oxygen isotopes in precipitation in the northern part of the North China Plain: Climatology and inter-storm variability, Hydrol. Processes, 18, 2211-2222, doi:10.1002/hyp.5525.

Yan, W. J., S. Zhang, P. Sun, and S. P. Seitzinger (2003), How do nitrogen inputs to the Changjiang basin impact the Changjiang River nitrate: A temporal analysis for 1968-1997, Global Biogeochem. Cycles, 17(4), 1091, doi:10.1029/2002GB002029.

Yang, H., and A. J. B. Zehnder (2005), The south-north water transfer project in China-An analysis of water demand uncertainty and environmental objectives in decision making, Water Int., 30(3), 339-349, doi:10.1080/ 02508060508691874

Yang, S., M. Li, S. Dai, Z. Liu, J. Zhang, and P. Ding (2006a), Drastic decrease in sediment supply from the Yangtze River and its challenge to coastal wetland management, Geophys. Res. Lett., 33, L06408, doi:10.1029/2005GL025507.

Yang, S. L., J. D. Milliman, P. Li, and K. Xu (2010), 50,000 dams later: Erosion of the Yangtze river and its delta, Global Planet. Change, 75, 14-20, doi:10.1016/j.gloplacha.2010.09.006.

Yang, Z., H. Wang, Y. Saito, J. D. Milliman, K. Xu, S. Qiao, and G. Shi (2006b), Dam impacts on the Changjiang (Yangtze) River sediment discharge to the sea: The past 55 years and after the Three Gorges Dam, Water Resour. Res., 42, W04407, doi:10.1029/2005WR003970.

Yang, Z. F., Y. Wang, Z. Y. Shen, J. F. Niu, and Z. W. Tang (2009), Distribution and speciation of heavy metals in sediments from the mainstream, tributaries, and lakes of the Yangtze River catchment of Wuhan, China, J. Hazard. Mater., 166, 1186-1194, doi:10.1016/j.jhazmat.2008.12.034.

Yao, Q. Z., J. Zhang, Y. Wu, and H. Xiong (2007), Hydrochemical processes controlling arsenic and selenium in the Changjiang River (Yangtze River) system, Sci. Total Environ., 377, 93-104, doi:10.1016/j.scitotenv.2007. 01.088 .

Yao, Q. Z., Z. G. Yu, H. T. Chen, P. X. Liu, and T. Z. Mi (2009), Phosphorus transport and speciation in the Changjiang (Yangtze River) system, Appl. Geochem., 24, 2186-2194, doi:10.1016/j.apgeochem.2009.09.023.

Zappa, C. J., W. R. McGillis, P. A. Raymond, J. B. Edson, E. J. Hintsa, H. J. Zemmelink, J. W. H. Dacey, and D. T. Ho (2007), Environmental turbulent mixing controls on air-water gas exchange in marine and aquatic systems, Geophys. Res. Lett., 34, L10601, doi:10.1029/2006GL028790.

Zhang, J. (1995), Geochemistry of trace metals from Chinese river/estuary systems: An overview, Estuarine Coastal Shelf Sci., 41, 631-658, doi:10.1006/ecss. 1995.0082 .

Zhang, J., W. W. Huang, and Q. Wang (1990), Concentration and partitioning of particulate trace metals in the Changjiang (Yangtze River), Water Air Soil Pollut., 52, 57-70, doi:10.1007/BF00283114.

Zhang, J., Z. F. Zhang, S. M. Liu, Y. Wu, H. Xiong, and H. T. Chen (1999), Human impacts on the large world rivers: Would the Changjiang (Yangtze River) be an illustration?, Global Biogeochem. Cycles, 13(4), 1099-1105, doi:10.1029/1999GB900044.

Zhang, L., and K. Zhou (1992), Background values of trace elements in the source area of the Yangtze River, Sci. Total Environ., 125, 391-404, doi:10.1016/0048-9697(92)90403-F.

Zhang, Q., C. Xu, S. Becker, and T. Jiang (2006), Sediment and runoff changes in the Yangtze River basin during the past 50 years, J. Hydrol., 331, 511-523, doi:10.1016/j.jhydrol.2006.05.036. 